\title{
Remote sensing of vegetation in the Sudano- Sahelian zone: A literature review from 1975 to 2014
}

\author{
Martin Karlson and Madelene Ostwald
}

\section{Linköping University Post Print}

\section{Tweet}

N.B.: When citing this work, cite the original article.

Original Publication:

Martin Karlson and Madelene Ostwald, Remote sensing of vegetation in the Sudano-Sahelian zone: A literature review from 1975 to 2014, 2015, Journal of Arid Environments, (124), 257269.

http://dx.doi.org/10.1016/j.jaridenv.2015.08.022

Copyright: Elsevier

http://www.elsevier.com/

Postprint available at: Linköping University Electronic Press

http://urn.kb.se/resolve?urn=urn:nbn:se:liu:diva-121292 


\title{
Remote sensing of vegetation in the Sudano-Sahelian zone: A literature review from 1975 to 2014
}

\author{
Martin Karlson $^{\mathrm{a}, 1}$ and Madelene Ostwald ${ }^{\mathrm{a}, \mathrm{b}}$ \\ ${ }^{a}$ Centre for Climate Science and Policy Research, Department of Thematic Studies- \\ Environmental Change, Linköping University, Linköping 58183, Sweden \\ ${ }^{b}$ Centre for Environment and Sustainability, GMV, University of Gothenburg and Chalmers \\ University of Technology, Göteborg 405 30, Sweden
}

\begin{abstract}
Scarcity of in situ vegetation data inhibits research and natural resource management in the Sudano-Sahelian zone (SSZ). Satellite and aerial remote sensing (RS) constitute key technologies for improving the availability of vegetation data, and consequently the preconditions for scientific analysis and monitoring. The aim of this paper was to investigate how the hands-on application of RS for vegetation analysis has developed in the SSZ by reviewing the scientific literature published between 1975 and 2014. The paper assesses the usages and the users of RS by focusing on four aspects of the material (268 peer-reviewed articles), including publication details (time of publication, scientific discipline of journals and author nationality), geographic information (location of study areas and spatial scale of research), data usage (application of RS systems and procedures for accuracy assessments), and research topic (scientific objective of the research). Three key results were obtained: i) the application of RS to analyze vegetation in the SSZ has increased consistently since 1977 and it seems to become adopted by a growing number of scientific disciplines; ii) the contribution of African authors is low, potentially signaling a need for an increased transfer of knowledge and technology from developed countries; iii) RS has primarily been used to analyze changes in vegetation productivity and broad vegetation types, whereas its use for studying interactions between vegetation and environmental factors has been relatively low. This calls for stronger collaborative RS research that enables the mapping of additional vegetation variables of high relevance for the environmental problems facing the SSZ. Remotely sensed vegetation data are needed at spatial scales that suits the requirements of both research and natural resource management in order to further enhance the usefulness of this technology.
\end{abstract}

Keywords: remote sensing, vegetation, drylands, Sudano-Sahel, monitoring, natural resource management

\footnotetext{
${ }^{1}$ martin.karlson@liu.se
} 


\section{Introduction}

The semi-arid Sudano-Sahelian zone (SSZ) is located between the Saharan desert and the humid Guinean zone and stretches from the Atlantic coast to the Red Sea coast (Fig. 1). In this area, human prosperity is tightly coupled to vegetation resources since $\sim 80 \%$ of the rapidly growing population relies on traditional livelihood strategies, such as subsistence agriculture and livestock production (UNEP 2011). Vegetation constitutes a vital source of energy (Bailis et al. 2007), livestock fodder (Le Houerou 1980), construction material, food stuff, and medicine (Manning et al. 2009), and provides for a number of indispensable ecosystem functions (Mertz et al. 2012; Sinare and Gordon 2015), including soil erosion control (Wezel and Rath 2002), soil fertilization (Bayala et al. 2005; Gnankambary et al. 2008), atmospheric carbon sequestration (Saatchi et al. 2011), and ground water recharge (Ilstedt et al. 2007; Bargués Tobella et al. 2014). In addition, vegetation influences the regional climate by controlling the albedo, and thus land-atmosphere interactions (Charney 1975).

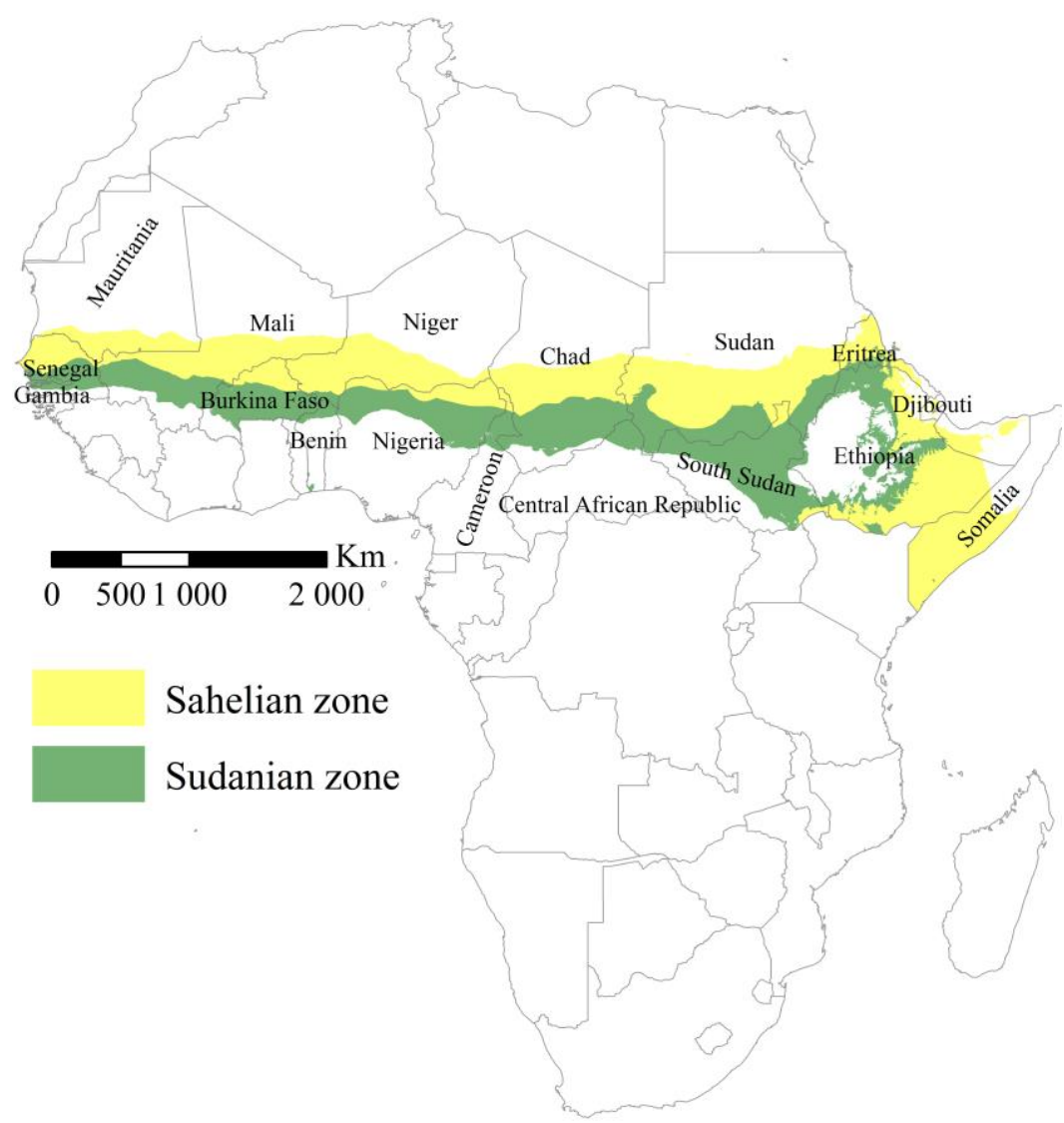

Fig. 1. Map showing the SSZ defined as the area between the $200 \mathrm{~mm}$ and $1000 \mathrm{~mm}$ isohyets (modified from Hijmans et al. 2005).

The condition of the vegetation in semi-arid areas in general, and the SSZ in particular, has been a matter of global concern for decades. It culminated in 1994 with the adoption of the United Nations Convention to Combat Desertification (UNCCD: Zeng 2003), which was one [Skriv här] 
of the three environmental conventions stemming from the Rio Summit in 1992. The predominating narratives of environmental change in the SSZ have conveyed a bleak picture where extensive population growth, destructive land management and strong climatic fluctuations have caused widespread and irreversible destruction of the vegetation cover and the soils, a process often referred to as desertification or land degradation (Lamprey 1975; Herrmann and Hutchinson 2005). The United Nations define desertification as 'land degradation in arid, semi-arid and dry sub-humid areas, resulting from various factors, including climatic variations and human activities', while land degradation is defined as 'the reduction or loss of biological or economic productivity and complexity of rainfed cropland, irrigated cropland, or range, pasture, forest and woodlands resulting from land uses or from a process or combination of processes...' (UN, 1994). The severe droughts that hit the SSZ in the early 1970s and the 1980s both reinforced this dystopic description of the situation and initiated a surge of interest in research about the causes of land degradation and desertification processes, and the effects on the environment and the climate (Tucker and Nicholson 1999). Much of the research originating from this period presented a more balanced picture and argued that earlier conceptions of large scale environmental change in the SSZ (e.g., marching deserts) in many cases have been ill-founded and exaggerated (e.g., Helldén 1991; Thomas and Middleton 1994; Tucker et al. 1991; Tucker and Nicholson 1999; Hiernaux et al. 2009; Fensholt and Rasmussen 2011).

Much of the confusion and the sweeping generalizations that have characterized the desertification debate in the SSZ can be traced to an inadequate understanding of the regional vegetation dynamics resulting from a deficiency of field observations and rigorous scientific research (Helldén 1991; Turner 2003). Even though the situation has improved, in situ vegetation data are still scarce in the SSZ (Mougin et al. 2009; Kergoat et al. 2011), inhibiting possibilities to improve scientific understanding, monitoring and management of this essential resource. This is a significant problem, especially in light of the highly uncertain, but potentially detrimental, impacts resulting from anthropogenic climate change, including changes in temperature and rainfall patterns (Giannini et al. 2013), and rapid population increases (Potts et al. 2013). Adequate availability of vegetation data is a prerequisite for the design and implementation of sustainable land management strategies and natural resource monitoring programs, including measures for climate change adaptation and mitigation, and famine early warning systems. Up to date vegetation data (e.g., carbon stocks and forest cover extent) of high quality are also needed for nations to comply with global monitoring and reporting commitments, such as those imposed by the United Nations Framework Convention on Climate Change (UNFCCC) and the Global Forest Resources Assessment (FRA) of the UN Food and Agricultural Organization (FAO).

Remote sensing (RS) data, acquired by optical and microwave sensors mounted on satellites and airplanes, are important alternative sources of information for monitoring and analysis of vegetation (DeFries 2008; Ustin and Gamon 2010). The main advantages of RS include i) the ability to observe large and inaccessible areas, ii) repeated and consistent data acquisition, iii) availability of historical datasets, and iv) low costs of data acquisition relative to field observations. At present, there is a wealth of operational RS systems with different spectral, 
spatial and temporal characteristics available, including the Advance Very High Resolution Radiometer (AVHRR), the Moderate Resolution Imaging Spectroradiometer (MODIS) and the Landsat series (see Table 1 for details on common RS systems). New earth observation satellites are also continuously being developed, for example the Sentinel-program of the European Space Agency (ESA). RS data with global coverage are available both in the format of un-processed data (e.g., spectral bands) and pre-processed products, such as leaf area index (LAI), fraction of absorbed photosynthetic active radiation (FAPAR), net primary production (NPP) and percent tree cover. Such data can be accessed online via a range of repositories, including the United States Geological Survey (USGS) and ESA. Recent trends in open access data policies and reduced software costs now open up for an increasingly larger group of users to take advantage of RS. The improving capacity and availability of RS is particularly promising for users of vegetation data that focus on areas such as the SSZ where field data are scarce (Mbow et al. 2014).

Table 1. Remote sensing systems commonly used for vegetation analysis in the SSZ. MS: multispectral, Pan: panchromatic.

\begin{tabular}{|c|c|c|c|c|c|}
\hline RS system & Resolution & $\begin{array}{l}\text { Revisit } \\
\text { period } \\
\text { (days) }\end{array}$ & $\begin{array}{l}\text { Scene } \\
\text { extent }(\mathbf{k m})\end{array}$ & Pixel size & $\begin{array}{l}\text { Launch } \\
\text { (year) }\end{array}$ \\
\hline AVHRR & Coarse -MS & $1-2$ & $2400 \times 2400$ & $1 \mathrm{~km}$ & 1978 \\
\hline VEGETATION & Coarse - MS & $1-2$ & $2250 \times 2250$ & $1.15 \mathrm{~km}$ & 1998 \\
\hline MODIS & Coarse/moderate MS & $1-2$ & $2330 \times 2330$ & $250 \mathrm{~m}-1 \mathrm{~km}$ & 1999 \\
\hline Landsat & Medium - MS & 16 & $185 \times 185$ & $\begin{array}{l}\text { MS: } 30-80 \mathrm{~m} \\
\text { Pan: } 15 \mathrm{~m}\end{array}$ & 1972 \\
\hline $\begin{array}{l}\text { Satellite Pour l'Observation } \\
\text { de la Terre (SPOT) }\end{array}$ & Medium - MS & $1-5$ & $60 \times 60$ & $\begin{array}{l}\text { MS: } 8.8-20 \mathrm{~m} \\
\text { Pan: } 2.2-10 \mathrm{~m}\end{array}$ & 1986 \\
\hline ASTER & Medium - MS & 16 & $120 \times 150$ & MS: $15-30 \mathrm{~m}$ & 2000 \\
\hline IKONOS & High - MS and pan & $3-5$ & $11 \times 11$ & $\begin{array}{l}\text { MS: } 4 \mathrm{~m} \\
\text { Pan: } 1 \mathrm{~m}\end{array}$ & 1999 \\
\hline
\end{tabular}

The large interest in RS for observation of vegetation in the SSZ is reflected in three recent scientific literature reviews, each focusing on a specific application area. Eisenfelder et al. (2012) review the use of RS for mapping vegetation biomass in semi-arid areas, including the SSZ. Knauer et al. (2014) present a detailed overview of how RS has been used to analyze vegetation dynamics in West Africa, and conclude that most of the research has been focusing on areas in the SSZ. Lastly, Mbow et al. (2015) provide a critical assessment of the research that has used RS for detecting desertification and land degradation in the Sahel. Together, these three papers provide a comprehensive description of the technological and methodological advancement of RS for vegetation observation in the SSZ, where the main focus is on the strengths and weaknesses of different RS systems and analytical methods. In contrast, the objective of the present paper is to investigate how the hands-on application of RS for vegetation analysis has developed in the SSZ between 1975 and 2014. The focus of this literature review is therefore on two subjects: the usages and the users of RS. Here, the usages involve the vegetation properties and processes that has been observed with RS in the 
SSZ, as well as the scope of the research where RS has been used to analyze vegetation. Questions about the users aim to characterize the researchers who use RS as a tool to study vegetation in this region. Four aspects of the literature are assessed quantitatively to accomplish the objective, including i) publication details (time of publication, scientific discipline of journals and author nationality), ii) geographic information (location of study areas and spatial scale of research), iii) data usage (application of RS systems and procedures for accuracy assessments), and iv) research topic (scientific objective of the research). Information about these four aspects can enable the identification of trends in the RS usage that can help pinpoint areas in need of prioritization, and thus further improve the usefulness of RS in the SSZ.

\section{The Sudano-Sahelian zone (SSZ) - environmental characteristics and implications for remote sensing}

The SSZ consists of two roughly parallel ecological regions and includes areas of 17 countries (Le Houron 1980; Nicholson 1995; Fig. 1). The Sahel is located on the fringes of the Sahara desert and covers the area that receives between 200 and $600 \mathrm{~mm}$ mean annual rainfall, while the Sudanian zone to the south receives between 600 and $1000 \mathrm{~mm}$ per year. The temperature in the SSZ follows a latitudinal gradient, with mean July temperature of $36^{\circ} \mathrm{C}$ in the north and $26^{\circ} \mathrm{C}$ in the south (Nicholson 1995). January is the coldest month with temperatures between $20^{\circ} \mathrm{C}$ in the north and $22-25^{\circ} \mathrm{C}$ in the south. The main rainfall patterns are also characterized by a latitudinal gradient, and a relatively short wet season, which takes place between May and October. These two distinct seasons are the result of the West African monsoon (Nicholson 2009). A fundamental feature of the Sudano-Sahelian rainfall patterns is the strong spatio-temporal variability (Nicholson 2001; 2013). This is seen by large fluctuations in rainfall levels between decades, years, months and locations. Between 1968-1997 annual rainfall levels declined by 20-40\% compared to the period between 19301960. Severe droughts struck the area during the years 1972-73 and 1983-84, which caused widespread famine (Hulme 2001). Since the mid-1980s rainfall levels have generally increased (Lebel and Ali 2009; Fensholt and Proud 2012), but the risk of periodic droughts is still high as was seen in 2012. The high climatic variability is also manifested by extreme rainfall events that frequently cause devastating floods (Tschakert et al. 2010). Low economic development, strong population increases, social unrest (e.g., conflicts in Mali, Nigeria and the Central African Republic) and climate change further add to the already high vulnerability of the local population and put pressure on vegetation resources (Potts et al. 2013).

The morphological structure and the floristic composition of the vegetation in the SSZ is primarily dependent on soil properties and rainfall levels (Le Houron 1980; White 1983; Nicholson 1995), but has also been shaped by long-term human land use (Fairhead and Leach 1995; Maranz 2009). In general, the proportion of woody vegetation (i.e., trees and shrubs), vegetation height, and vegetation density increase in a north to south direction. The most northern area (Sahel) is composed of grasslands dominated by annual species, and a sparse woody cover of drought tolerant species, such as the Acacia genus (Hiernaux et al. 2009). A 
large proportion of the land is bare and vegetation tends to grow in patches, where the most striking example is the tiger bush formation (Nicholson 1995). Livestock production is the main means for subsistence in this area (Batterbury and Warren 2001). Further south in the Sudanian zone, grassland savannas characterized by perennial grasses and woodland/agroforestry parkland landscapes dominate (Boffa 1999). The main means for subsistence in the Sudanian zone is small scale rain-fed agriculture, in combination with livestock production. In the southern areas of the Sudanian zone the tree density increases to form dry forests, which transcend into the humid forests of the Guinean zone to the south (White 1983; Nicholson 1995).

Water is the main limiting factor for vegetation growth throughout the SSZ, which means that photosynthesis mainly takes place during the wet season (Philippon et al. 2005). This results in a distinctly phased vegetation phenology with an intense green-up shortly after the first rains and a high degree of grass and leaf senescence at the beginning of the dry season. The strong intra-seasonal and inter-annual climate variability influences the prevalence of "green" biomass (leafs and grass), and thereby the spectral properties of vegetation (i.e., spectral differences in reflection, absorption and transmittance of electromagnetic radiation, which are the main information carriers in RS). The high variability in vegetation conditions, together with the patchy landscape structure, the open vegetation canopy and the heterogeneous soil conditions, are all factors that pose challenges for RS of vegetation in the SSZ (Franklin 1991; van Leeuwen et al. 1994; Kammerud 1996; Leprieur et al. 2000).

\section{MATERIAL AND METHODS}

\subsection{Literature search}

The literature search included English peer-reviewed articles that published original research between 1975 and 2014. Relevant articles were initially identified using targeted searches in the SCOPUS and the ISI Web of Knowledge databases. The inclusion/exclusion criteria for the selection encompassed i) use of RS data for vegetation analysis, ii) geographical location (i.e., study was conducted within the SSZ) and iii) publication in a scientific journal.

Additional articles were identified in relevant literature reviews, and in the reference lists of the included articles through backward reference list checking (Gough et al. 2012). We limited this review to literature concerning RS of (semi-) natural vegetation (i.e., trees, shrubs and grasses). Thus, research that used RS for agricultural applications (e.g., crop estimation) and for bush fires mapping were omitted from the selection.

\subsection{Content analysis}

The articles that met the inclusion/exclusion criteria in the literature search were assessed following the steps in Fig. 2. The sections below provide additional information to the different steps of the content analysis. 
i) Publication Details

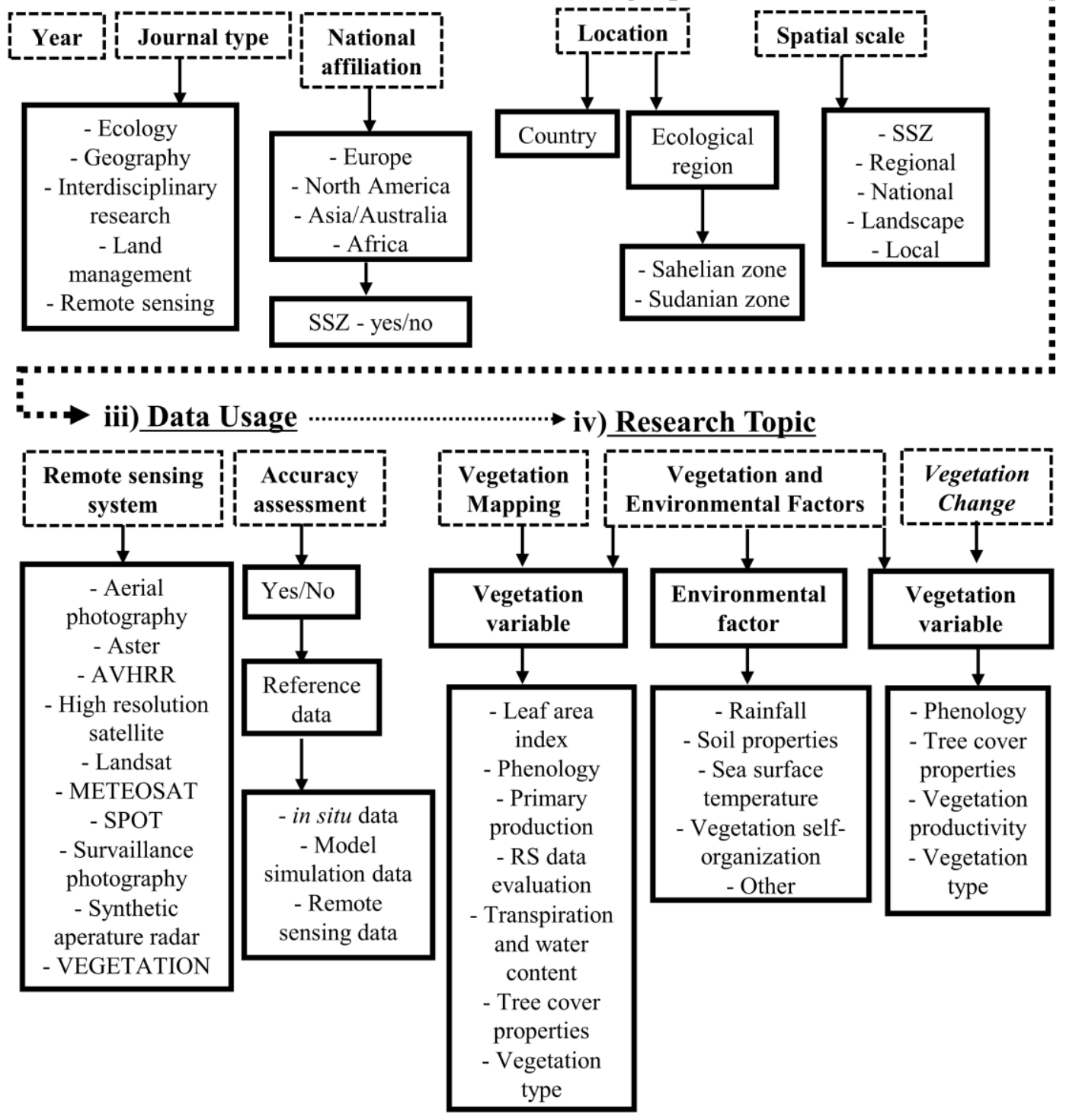

Fig. 2. Flowchart that describes the content analysis process. The broken boxes indicate the main categories used for assessing each aspect of the review material. The solid boxes indicate the sub-categories and the possible options within them.

\section{i) Publication details}

Each article was assessed regarding year of publication, journal type and national affiliation of the authors. The journals were divided into five disciplinary categories based on their respective aim and scope. We acknowledge that many journals do not conform to crisp disciplinary boundaries and that such a categorization is arbitrary by default. Thus, results based on the categorization are intended to be seen as an indication of disciplinary acceptance of RS.

\section{ii) Geographical information}

The study areas of each article were assessed regarding location and spatial scale (extent) of the analysis. Information about location focused on the country and the ecological region of 
each study. Five categories were used to define the spatial scale of the study areas, including i) SSZ scale, ii) regional scale (areas of multiple countries), iii) national scale (whole country), iv) landscape scale $\left(\geq 1000 \mathrm{~km}^{2}\right)$ and v) local scale $\left(<1000 \mathrm{~km}^{2}\right)$.

\section{iii) Data Usage}

The assessment about data usage included quantifying the application of different RS systems. We also identified whether accuracy assessments had been conducted and identified the type of reference data used.

\section{iv) Research Topic}

The articles were grouped into three main categories based on the objective of the research, including i) vegetation mapping, ii) vegetation and environmental factors and iii) vegetation change, following the typology for vegetation ecology proposed by van der Maarel (2005). Articles can have multiple research objectives and may therefore be included in more than one of the main categories. The three main categories are further divided into sub-categories based on the specific focus of the research (Fig. 2).

The category vegetation mapping includes research that uses RS to map properties of the vegetation cover, including structural, biochemical and floristic attributes. It also includes research where the quality of RS data, in particular time series, is evaluated through comparisons to in situ observations (e.g., derived from spectroradiometers; Fensholt et al. 2004), or observations from other satellite sensors (e.g., AVHRR NDVI vs. MODIS NDVI; Fensholt et al. 2009). The category vegetation and environmental factors includes research that investigates relationships between vegetation and the surrounding environment. Such analyses are achieved by correlating vegetation attributes and their dynamics with environmental factors, such as altitude, soil properties, temperature, and rainfall. Research in the last category investigates vegetation change resulting from climatic and/or anthropogenic disturbances (e.g., drought, land use and migration). This category includes the large body of research that has been scrutinizing desertification and land degradation processes in the SSZ. The distinction between the categories vegetation and environmental factors and vegetation change is less obvious in certain instances, in particular because of the close connection between vegetation production and rainfall in the SSZ. Specifically, analyses of vegetation change often aim to separate long term trends from short term climate fluctuations (i.e., interannual rainfall variability), which requires that the relationship between vegetation production and rainfall is taken into account in the analysis.

\section{RESULT}

\subsection{Publication details}

The literature search had 1975 as the starting year; however, no relevant articles were published in the first two years of the period (Fig. 3). The first publication occurred in 1977 (Oduolowu 1977), and since then the use of RS in vegetation analyses in the SSZ have been increasing steadily reaching 268 published articles at the end of 2014. The first substantial increase in publication activity occurred in the late 1980s. At the end of the 1990s and in the 
early 2000s, a new relatively strong increase occurred. During the years between 2007 and 2012 the annual publication rate increased to surpass one article per month on average. The last two years of the period (2013-2014) clearly stand out because the publication rate has more than doubled compared to the preceding time period.

\section{Number of articles $(n=268)$}

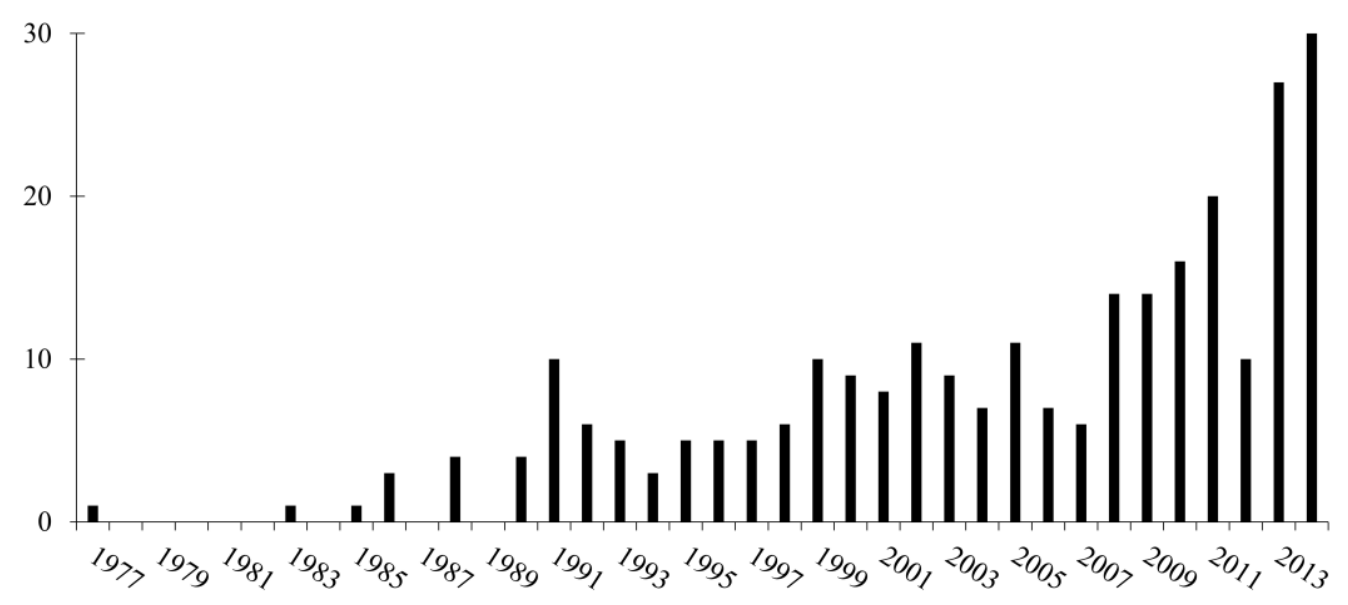

Fig. 3. Temporal development of published articles where remote sensing has been used to analyse vegetation.

The articles appeared in 84 different scientific journals. About half of the articles were published in journals with a specific focus on RS applications, while the distribution of the other half is more scattered between the journal categories (Table 2). Furthermore, the distribution of articles in the respective categories has changed over time. In the first period (1975-1987) the majority of the articles were published in RS journals and the other categories had limited representation (geography) or were absent (ecology, land management and ecology). Between 1988 and 2001, articles about RS started to be published more frequently in other types of scientific journals. A similar pattern can be seen in the most recent period (2002-2014) where the distribution between the journal categories has become more even and the number of articles published in ecological, geographical, interdisciplinary and land management oriented journals have increased considerably.

Table 2: Distribution of articles in journal categories and the temporal development of the place for publication.

\begin{tabular}{lcccccc|cc}
\hline & $\mathbf{1 9 7 5 - 1 9 8 7}$ & \multicolumn{2}{c}{$\mathbf{1 9 8 8 - 2 0 0 1}$} & \multicolumn{2}{c|}{$\mathbf{2 0 0 2 - 2 0 1 4}$} & \multicolumn{2}{c}{ Total } \\
Type of journal & No & $\%$ & No & $\%$ & No & $\%$ & No & $\%$ \\
\hline Ecology & & & 8 & 11 & 20 & 11 & 28 & 10 \\
Geography & 1 & 17 & 11 & 15 & 20 & 11 & 32 & 12 \\
Interdisciplinary & & & 7 & 10 & 38 & 20 & 45 & 17 \\
Land Management & & & 3 & 4 & 24 & 13 & 27 & 10
\end{tabular}




\begin{tabular}{l|cccccc|cc} 
Remote Sensing & 5 & 83 & 43 & 60 & 88 & 46 & 136 & 51 \\
\hline Total no. & 6 & & 72 & & 190 & & 268 & \\
\hline
\end{tabular}

The majority of the articles' first authors have been affiliated with institutions located in Europe and North America. Institutions in Africa and Asia/Australia have much lower representation (Fig. 4). Fig. 4 further shows that the African co-authorship is generally low.

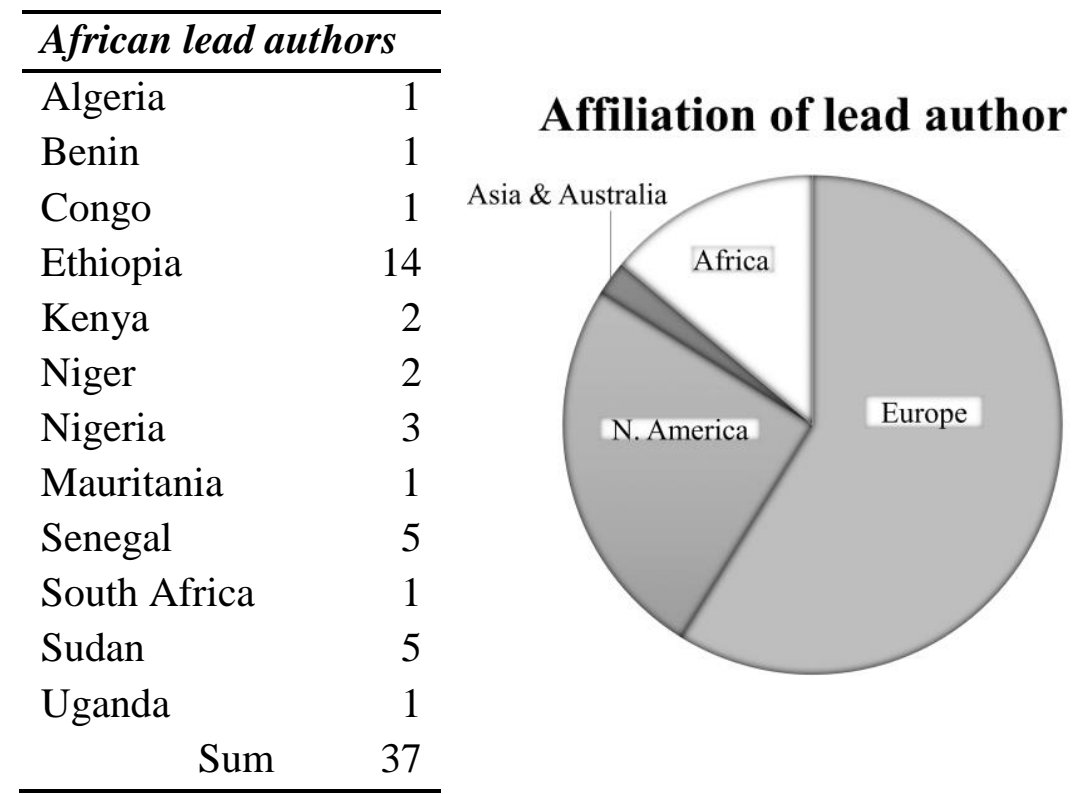

\begin{tabular}{lccll}
\hline & $\begin{array}{l}\text { \%of total co- } \\
\text { authors }(\boldsymbol{n}=\mathbf{7 4 9})\end{array}$ & $\begin{array}{l}\text { No of } \\
\text { articles }\end{array}$ & $\begin{array}{l}\text { \% of total articles } \\
(\boldsymbol{n}=\mathbf{2 6 8})\end{array}$ \\
\hline African co-authors & 129 & 17 & 78 & 29 \\
\hline
\end{tabular}

Figure 4. National affiliation of lead- and co-authors to remote sensing literature in the SSZ.

\subsection{Geographical information}

As seen in Fig. 5, the geographic distribution of the scientific activities is uneven in the SSZ. Considerably more research has been conducted in the western parts of the SSZ compared to the east, and more research has been conducted in the Sahelian zone compared to the Sudanian zone. On the national level, it is clear that Chad, Mauritania, Nigeria, Somalia and South Sudan, as well as small countries (Djibouti, Eritrea and the Gambia) and countries with limited spatial overlap with the SSZ (Benin, Cameroon and the Central African Republic), have received limited attention during the 39-year period. Senegal is the country where the largest proportion of research has been conducted, followed by Burkina Faso and Niger. 


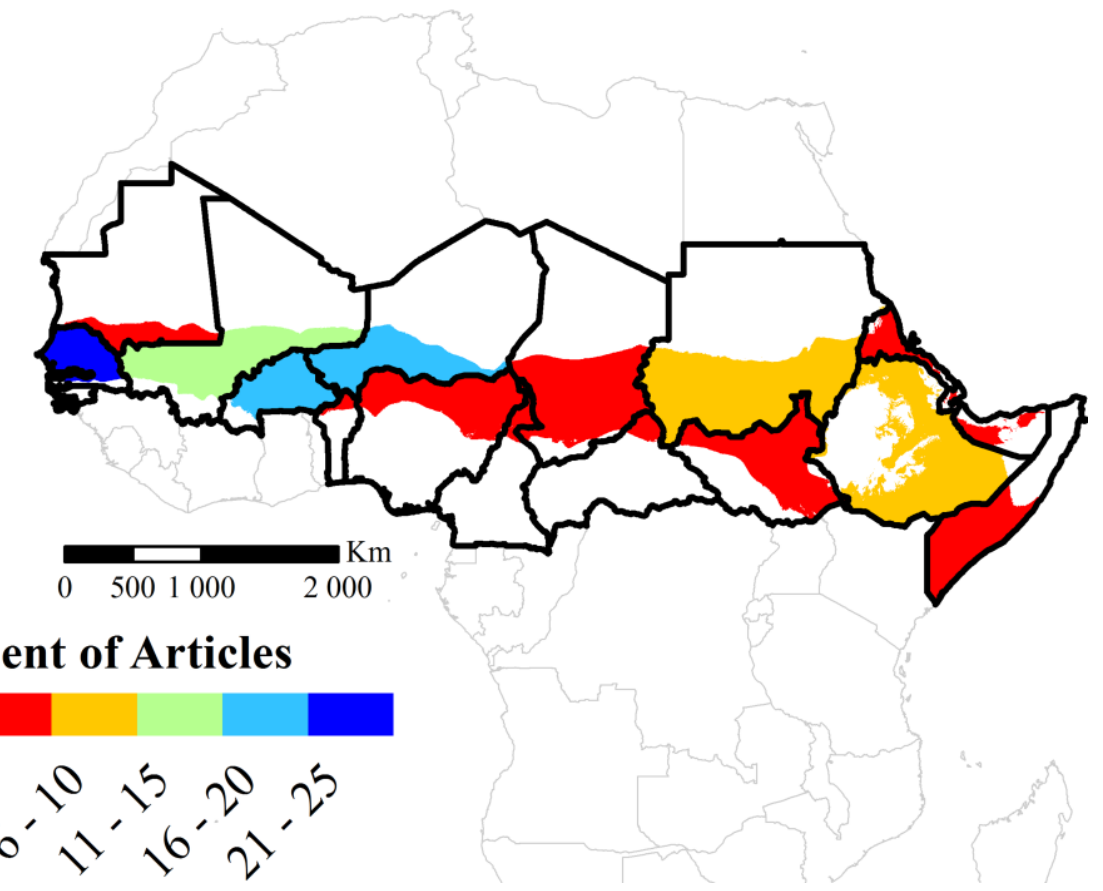

Fig. 5. The percentage of articles published within each country. 49 studies conducted research on the SSZ scale, which are not included.

The largest proportion of the research, which applied RS data for vegetation analysis, was conducted on the local scale (Fig. 6). Landscape scale and SSZ scale analysis was the second and third largest categories. Figure 6 also shows the temporal development of the choice of scale for the study areas. It appears that the amount of landscape and SSZ scale research has increased over time, whereas no clear temporal trend can be seen for the other three spatial scale categories.

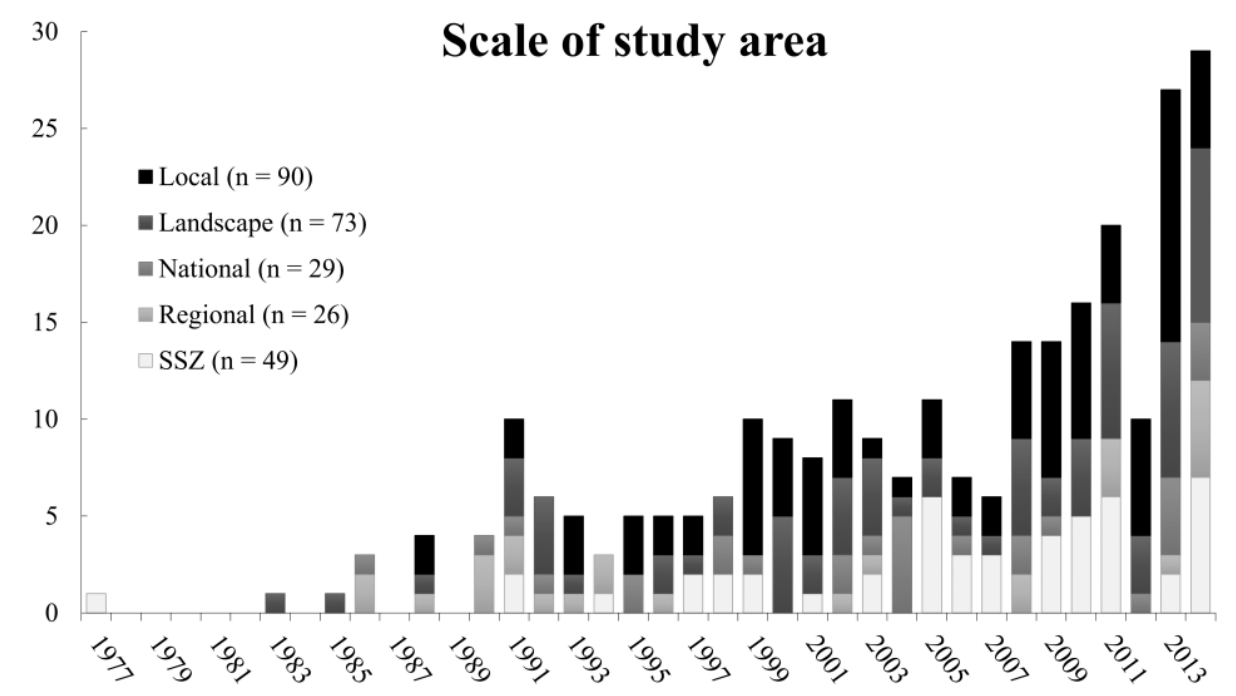

Fig. 6. Temporal development of the spatial scale (i.e., extent of study areas) applied to analyse vegetation using remote sensing. 


\subsection{Data usage}

It is clear from Fig. 7 that the NOAA AVHRR and Landsat series of satellites have been the dominant RS systems for vegetation observation in the SSZ. Furthermore, coarse or moderate resolution RS systems (i.e., AVHRR, MODIS, METEOSAT, VEGETATION and SAR) are the most common choice in this region. Landsat dominates in the medium resolution category (i.e., Landsat, SPOT and Aster), while aerial photography is the most frequently applied type of high resolution RS data.

\section{Remote sensing systems}

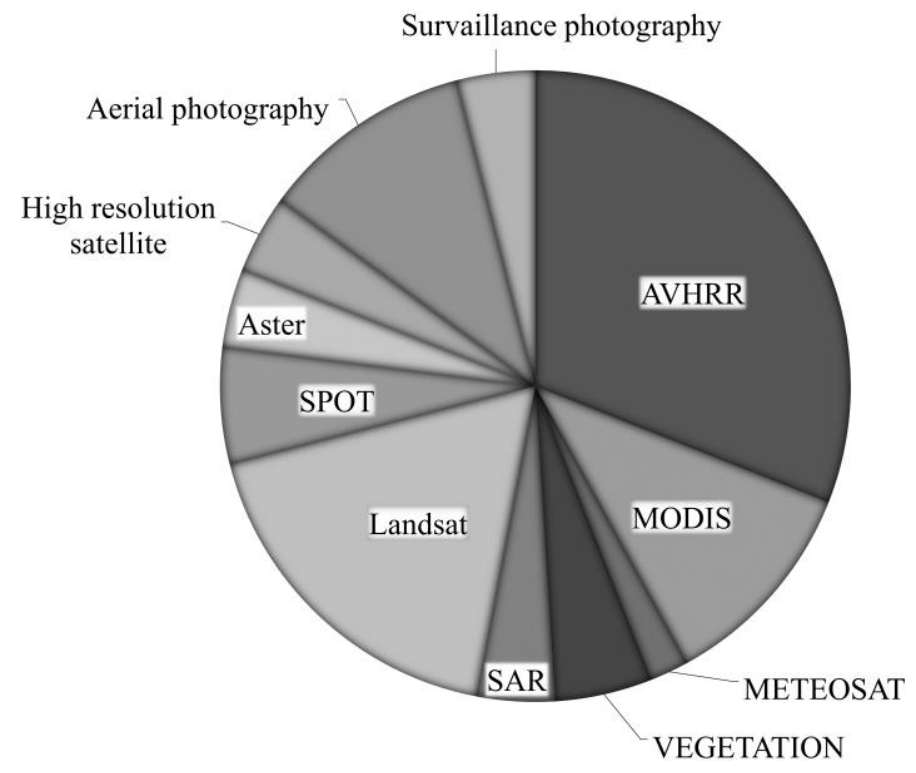

Fig. 7. Remote sensing systems used to analyse vegetation in the Sudano-Sahelian zone.

The main part of the reviewed studies assessed the accuracy of the remotely sensed vegetation variables using an independent reference dataset (Table 3). Most accuracy assessments were performed using in situ data. Higher resolution RS data, data from model simulations and historical photographs were used less frequently for accuracy assessments.

Table 3. Performance of accuracy assessment and use of different sources of reference data.

Accuracy assessments and reference data

\begin{tabular}{l|lc}
\hline & Reference data & No of studies \\
\hline No & & 77 \\
\hline \multirow{5}{*}{ Yes } & In situ data & 191 \\
& Remote sensing & 150 \\
& Model data & 34 \\
& Photographs & 6
\end{tabular}




\subsection{Research topic}

The vegetation mapping category was dominated by research with the objective to either map primary production directly, to estimate variables used in primary production modelling (e.g., absorbed photosynthectically active radiation and production efficiency indicators), or to generate spatially explicit forecast of primary production (Fig. 8). Relatively few studies have explored techniques for the mapping of tree cover attributes and vegetation types in the SSZ. Research on tree cover attributes has mainly focused on mapping tree canopy cover (\%) and tree density (trees/ha), and to a lesser extent aboveground biomass (tons/ha) and tree height (m). Research in the RS data evaluation category did not map or analyse vegetation per se, but instead performed assessments of the quality of different RS dataset, including the consistency of time series. For example, the quality of NDVI datasets has been evaluated against in situ spectral measurements, and the consistency long-term NDVI time series (e.g., AVHRR) have been evaluated using more recent satellite systems (e.g., MODIS). This category also includes research that has explored effects on RS data resulting from external factors, such as sun-sensor geometry and cloud coverage.

\section{Vegetation mapping}

$(37 \%)$

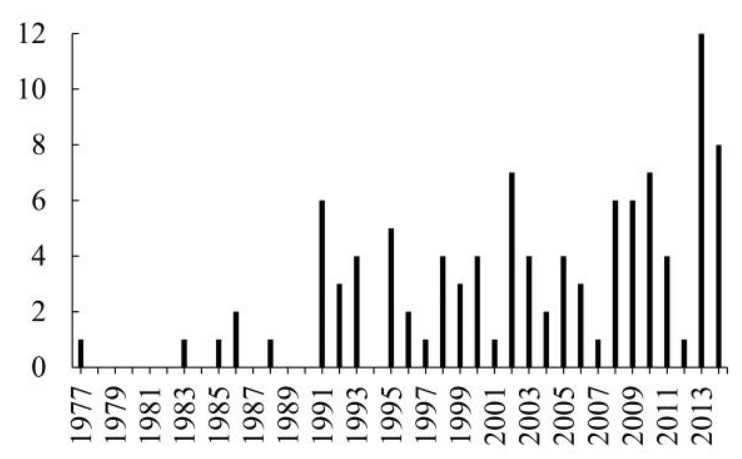

Vegetation variables

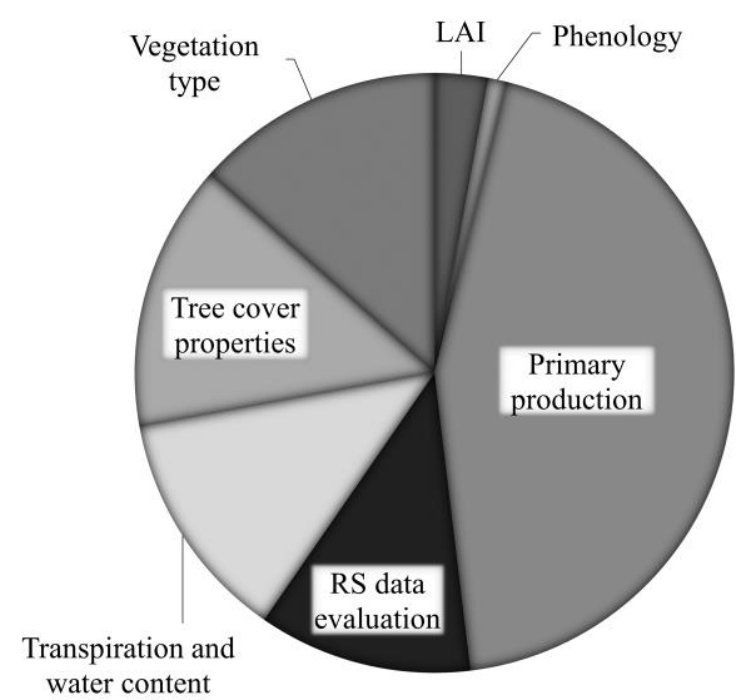

Fig. 8. Temporal and thematic distribution of the category vegetation mapping $(n=104)$.

The category vegetation and environmental factors included the lowest number of articles in the typology. Research within this category has mainly focus on the relationship between vegetation and rainfall (Fig. 9a). Other environmental factors that have been studied for their influence on vegetation dynamics include soil properties and sea surface temperature. Furthermore, some articles in this category used RS data to analyse self-organization of vegetation systems in order to explain the ecological processes causing banded or spotted vegetation patterns, which are commonly occurring in parts of the Sahel (Nicholson 1995). Different vegetation variables, observed through $\mathrm{RS}$, have been correlated with environmental factors (Fig. 9b). Most research has studied the influence of environmental factors on vegetation production. Other vegetation variables that has been used less [Skriv här] 
frequently in this type of research, include tree cover attributes, phenology and vegetation types.

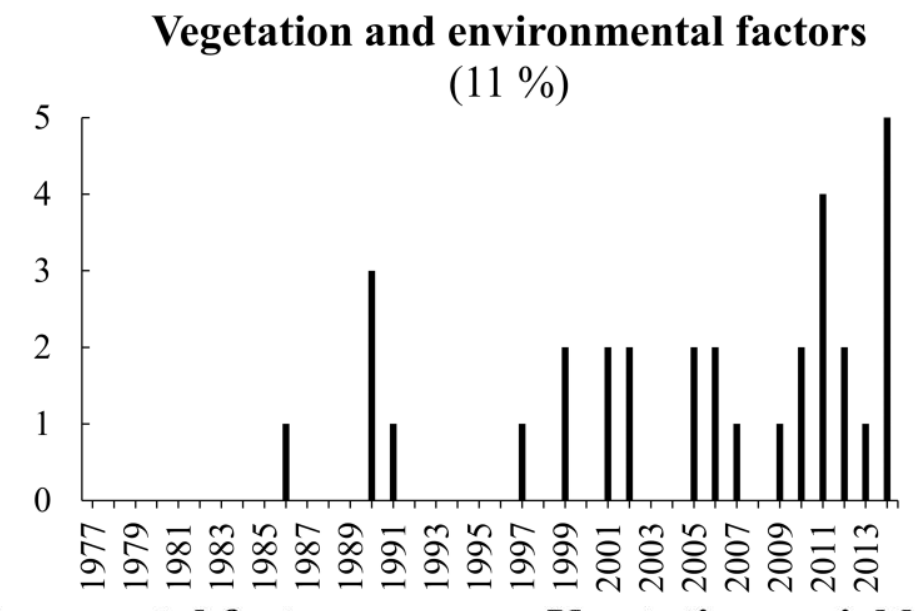

Environmental factors
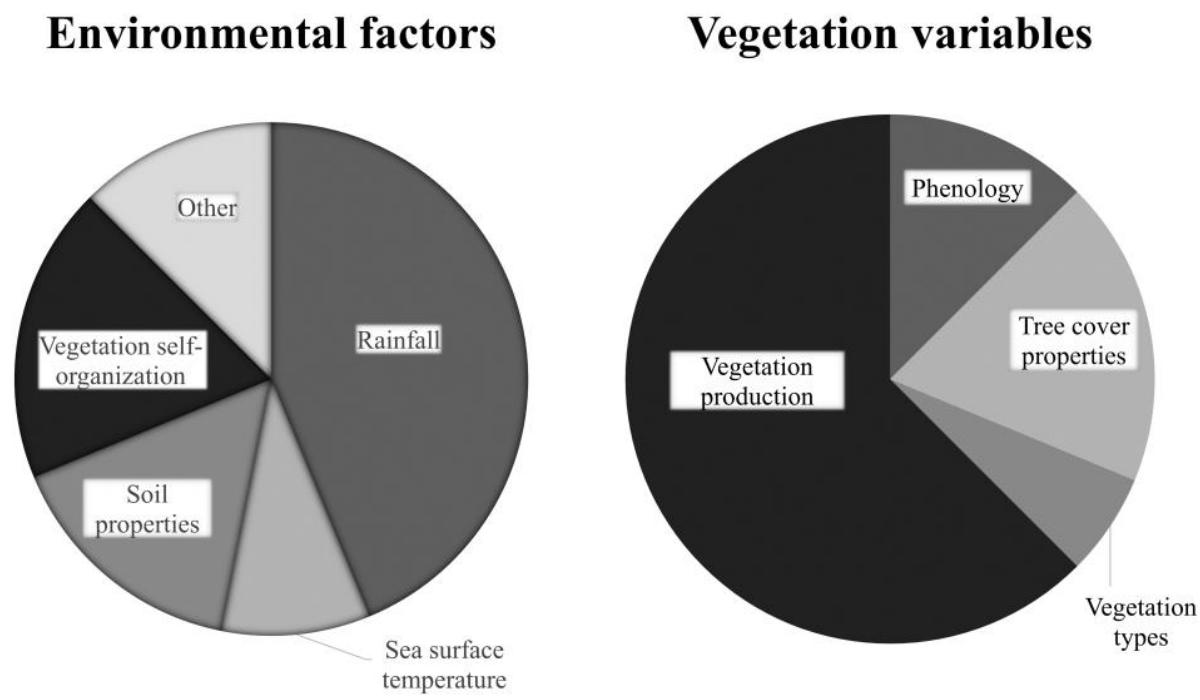

Fig. 9. Temporal (a) and thematic distribution (b) of the category vegetation and environmental factors $(n=32)$.

The category vegetation change constitute more than half of the review material, which suggests that this is the primary application area of RS data in the SSZ (Fig. 10). Different vegetation variables have been in focus for vegetation change research in the SSZ. The largest proportion of the research has used thematic mapping approaches where high (e.g., aerial photography) or medium (e.g., Landsat) resolution RS data from selected years are processed individually to derive time series of maps that depict land cover and/or vegetation types. Vegetation changes are then typically detected using post-classification comparison. The second most common variable for vegetation change analysis in the SSZ is vegetation productivity derived from time series of coarse resolution RS data (e.g., AVHRR). Knauer et al. (2014) and Mbow et al. (2015) provide detailed descriptions of the many different approaches have been used to detect changes in vegetation productivity using coarse resolution RS data in the SSZ. Considerably less research has analysed changes in tree cover attributes and vegetation phenology using RS data. Changes in tree cover attributes (e.g., canopy cover and tree density) have primarily been analysed using high or medium resolution 
RS data in order to separate trees and shrubs from the herbaceous vegetation that dominate the RS signal during the growing season. However, recent research by Horion et al. (2014) and Mitchard and Flintrop (2013) has shown that coarse resolution NDVI data acquired during the dry season is an interesting alternative for analysing tree cover changes over larger spatial extents (Brandt et al. 2015).
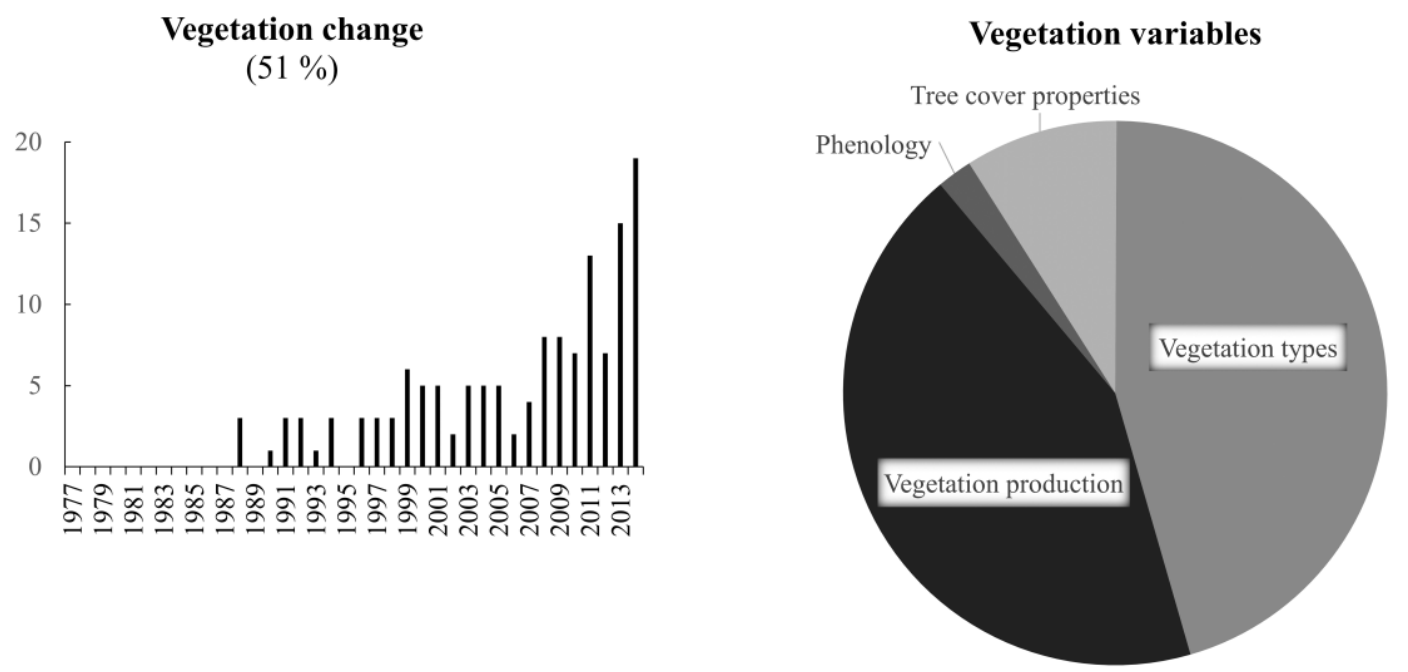

Fig. 10. Temporal and thematic distribution of the category vegetation vegetation change $(\mathrm{n}=$ 143).

\section{DISCUSSION}

\subsection{What information can remote sensing provide about vegetation in the Sudano- Sahelian zone?}

The category vegetation mapping include research where RS systems have been evaluated for their potential to map different vegetation variables, while vegetation and environmental factors and vegetation change include research where RS been used as a tool to analyze dynamics and changes in these remotely sensed variables. A comparison between the three categories (Fig. 8-10) shows that a few vegetation variables have dominated the applied research categories (i.e., vegetation and environmental factors and vegetation change). Vegetation production has been the main variable for research focusing on vegetation dynamics and changes on broad spatial scales, whereas mapping of vegetation types has dominated analyses that focus on smaller areas.

The large focus of RS research on vegetation production and broad vegetation types is likely a reflection of both the prevailing environmental concerns in the SSZ, in particular desertification/land degradation, and practical considerations related to availability of RS data and methods for RS data interpretation. Vegetation production has historically been a key variable to describe the state and the dynamics of the Sudano-Sahelian environment and its relation to land use (Le Houérou 1989), and is also included in the definition of desertification/land degradation used by the UNCCD (2014). In the late 1990s, widespread increases in vegetation production were observed throughout the SSZ (i.e., greening; Olsson et al. 2005) using AVHRR time series. This rather unexpected finding further challenged the 
dominating narrative of environmental change in the SSZ, and is one of the main reasons for the large increase in RS research in the last 15 years shown in this review. Several researchers suggested that the greening-phenomenaon needed to be observed at higher levels of detail in order to establish the causative mechanisms and to better understand potential consequences (Anyamba and Tucker 2005; Herrmann et al. 2005). Time series of medium and high resolution RS data have been widely used for such analyses because fine scale processes, including human influences on vegetation, can be observed (e.g., Kelder et al. 2013; Rasmussen et al. 2014; Ruelland et al. 2008; 2010; Tappan et al. 2000; 2004). Other researchers have explored hotspots of vegetation change identified by coarse resolution RS through field based surveys and interviews with local land users (e.g., Milich and Weiss 2000; Herrmann and Tappan 2013; Brandt et al. 2014a; 2014b; Herrmann et al. 2014).

There are also practical reasons for the large focus on RS of vegetation production and vegetation types. Coarse resolution NDVI data has a long tradition in RS applications and was initially accepted as a reliable proxy for vegetation productivity in semi-arid ecosystems (Prince and Justice 1991). Consequently, analyses of vegetation productivity dynamics and changes using NDVI have been less dependent on the availability of reference data for calibration and validation, which has greatly facilitated its widespread application in the SSZ. Thematic mapping of broad vegetation types also has a long tradition in RS research in general, and the availability of established and easily accessible methods (i.e., implemented in standard software suits) for manual and automated data interpretation has contributed to their widespread adoption (Ustin and Gamon 2010). Thematic mapping requires reference data for training classification algorithms and for validation, which has largely restricted the application to local scales in the SSZ. National and regional scale analyses using thematic mapping have been conducted, for example in Senegal (Tappan et al. 2004), the Horn of Africa (Brink and Eva 2011) and West Africa (Vitek et al. 2014). However, such broad scale studies have used a systematic spatial sampling strategy instead of complete coverage imagery in order to limit the data processing burden, and have relied on local experts for data interpretation. Recent examples exist where high resolution imagery accessed from Google Earth has been used as reference data for medium resolution data interpretation (Rembold et al. 2013; Wu et al. 2013; Karlson et al. 2015). High resolution imagery represents an interesting complement to in situ data and may reduce the costs and risks (e.g., due to social unrest) associated with field campaigns (Rembold et al. 2013).

Both these two widely studied vegetation variables (i.e., vegetation productivity and vegetation types) have limitations to characterize the heterogeneous vegetation cover in the SSZ. Specifically, vegetation production estimates derived from coarse resolution RS data provide poor spatial detail due to their large pixel size (e.g., 1-64 km² for AVHRR).

Assessments have also shown that the relationship between NDVI and vegetation production in the SSZ is complex and influenced by both internal and external factors, including species composition (Tagesson et al. 2014), water availability (Diouf and Lambin 2001; Fensholt et al. 2013) and soil reflectance (Kammerud 1996). In addition, vegetation production derived from NDVI time series mainly capture the contribution from herbaceous vegetation which dominates over the sparse tree cover in terms of spectral response at the scale of coarse 
resolution pixels (Gonzalez et al. 2012), especially during the wet season (Horion et al. 2014). As for vegetation types, the crisp classification boundaries inherent to thematic mapping are far from ideal to capture subtle, yet potentially important, variations in the heterogeneous vegetation cover in the SSZ (Franklin 1991; Cord et al. 2010). Furthermore, time series of vegetation maps consisting of a few time steps (e.g., decadal) have limitations to capture the temporal dynamics that characterize vegetation in the SSZ. Consequently, these two variables may therefore conceal important aspects of both vegetation dynamics and vegetation change.

\subsection{Local remote sensing capacity - a function of knowledge transfer and research infrastructure}

The geographic distribution of the research is uneven throughout the SSZ (Fig. 5). A large proportion of the RS research has been conducted in the western parts of the SSZ (e.g., Burkina Faso, Niger and Senegal), whereas considerably less research has been conducted in the eastern parts. This pattern is presumably shaped by research priorities and investments made by institutions in the individual countries that is further accentuated by the placement of large international research projects, such as the Hydrologic-Atmospheric Pilot Experiment (HAPEX) in the Sahel (Goutorbe et al. 1997) and the African Monsoon Multidisciplinary Analysis (AMMA; Kergoat et al. 2011; Mougin et al. 2009). Bilateral collaborations between national governments and universities have likely contributed to this pattern as well, for example Denmark has had a strong presence in Burkina Faso and Senegal (Mbow et al. 2014). Understandably, considerably less research has been conducted in politically unstable areas, including areas where armed conflict has prevailed in the recent past (e.g., Chad, Sudan and Somalia).

The geographic publication pattern demonstrates a spatial imbalance of RS capacity within the SSZ that potentially reflects impaired preconditions for research, monitoring and management of vegetation resources in a significant number of countries. Furthermore, the low number of both lead- and co-authors with African affiliations suggests that the research conducted in the SSZ has mainly been initiated, conducted and financed by foreign institutions, generally located in Europe and North America. Even though it is well known that the general development of RS usage in Africa has been severely hampered by bureaucratic, financial and technical constraints (Abiodun 2000), it is noteworthy that the three countries (Burkina Faso, Niger and Senegal) where most of the RS research has been conducted in the SSZ have so low representation in terms of authorship. Similar observations were made by Woldai and Annegard (2010) for RS research in Africa in general. This raises questions about the degree to which RS technology and knowledge is transferred from developed countries to the countries where the research is conducted. These results further add to the conclusions by Romijn et al. (2012) who showed that countries in the SSZ have very low capacities to monitor forest carbon by RS compared to other tropical countries. Increased support for capacity building of local institutions in the SSZ, such as Centre de Suivi Ecologique (Senegal), the Centre Régional AGRHYMET (Niger), as well as local universities, may therefore be needed to promote an increased usage of RS. In addition, RS 
capacity is also highly depends on RS data availability. At present, a wide supply of high quality RS data is available free of charge and in the near future there will be the launch of the Sentinel-2 satellite, which will provide free data of unprecedented high spatial as well as temporal resolution (Drusch et al. 2012). An important consideration in this regard is that the possibility to download RS data in the SSZ presently is severely hampered by insufficient internet capacity (Roy et al. 2010; Romijn et al. 2012).

\subsection{Diversifying the use of remote sensing - a way forward?}

This review has identified an important gap between the present capability of RS and current vegetation information requirements in the SSZ. Specifically, local scale research has shown that climate change and land use change has caused degradation of the tree cover in different part of the SSZ (e.g., Gonzalez 2001; Maranz 2009; Gonzalez et al. 2012). Tree cover monitoring by RS on larger spatial scales is therefore needed to provide comprehensive descriptions of the process and establish whether it is operating on regional or continental scales. However, previous tree cover monitoring has mainly been conducted on local scale using thematic mapping approaches, which are limited in the ability to detect subtle changes in tree cover conditions, for example modifications in density, structure and composition (Lambin 1999). Two recent examples have shown that wide scale tree cover monitoring may be feasible using coarse resolution RS data, in particular dry season AVHRR NDVI (Mitchard and Flintrop 2013; Horion et al. 2014). This is an interesting approach that uses differences in phenology to separate the spectral signals from herbaceous and woody vegetation, which merits further research efforts. Several global tree cover products derived from MODIS (Hansen et al. 2003) and Landsat (Sexton et al. 2013) that provide higher spatial detail are also available to the scientific community, but they need to be validated locally to ensure that they provide reliable information (Sjöström et al. 2013). Rigorous assessments have been performed in some areas of the SSZ for other vegetation products, including MODIS LAI (Fensholt et al. 2004) and primary production products (Fensholt et al. 2006; Sjöström et al. 2009; 2011; 2013). Herrmann et al. (2013) assessed the MODIS tree cover product visually in a Faidherbia albida agroforestry landscape in Senegal and found it to severe limitations. Further assessments of pre-processed vegetation products in the different landscapes types of the SSZ can be facilitated by improving the cooperation between the different actors who collect vegetation data in the field and the RS community (Pettorelli et al. 2014). An example of such an initiative is the West African Vegetation Database of the UNDESERT project that provides an online platform for vegetation data exchange.

This review demonstrates that the usage of RS for vegetation analysis has increased consistently in the SSZ since the mid-1980s, but also that the RS users have diversified. Specifically, our analysis suggests that that the range of the journal used for publishing RS research have diversified consistently in terms of their scientific disciplines: the publications have moved from strictly RS oriented journals into journals specialized in land management, geography, ecology and interdisciplinary science. This may suggest that RS is increasingly being accepted as an effective source of vegetation information by a broader group of 
scientific practitioners who are active in the SSZ. The general trend of improving quality and accessibility of RS data suitable at different spatial scales will most likely facilitate this trend. However, this review also show that vegetation change is the dominating application area for RS in the SSZ, whereas its use in analyses of relationships between vegetation and environmental factors is still limited. In order words, the usages have not diversified in the same extent as the users. Hence, additional integration of RS into scientific disciplines concerned with other types of research questions about vegetation is needed to further advance the scientific contribution of this relatively young technology (Pettorelli et al. 2014). Such integration may strengthen capacities in the SSZ to assess and understand vegetation responses to environmental change and the related impacts on natural resources and human livelihoods.

In order to make RS useful for answering other research questions than those that have dominated in the SSZ previously, additional vegetation variables need to be mapped with sufficient accuracy and detail. Important topics for future RS research in the SSZ therefore include the mapping of i) morphological structure of woody vegetation (e.g., woody biomass, tree density, canopy cover and canopy height) and ii) floristic aspects (e.g., differentiation between annual and perennial grasses and between tree species types). In particular floristic aspects are missing links in the understanding of what is driving vegetation changes observed at coarse spatial resolutions (e.g., greening; Olsson et al. 2005; Tagesson et al. 2014), and how such changes impact the local environment and livelihoods (Herrmann et al. 2014). The Sentinel-2 mission, which is planned to be operational in 2016, will provide high spatial and temporal resolution data. These are highly suitable data characteristics for mapping and analyzing different aspects of the Sudano-Sahelian vegetation.

\section{CONCLUSIONS}

- The use of RS for vegetation analysis in the SSZ has increased steadily from 1975 to 2014 in terms of peer-reviewed articles $(n=268)$, with the largest increase in the last seven years.

- During the last 12 years, RS appears to have become increasingly accepted as a source of information by a wider group of researchers concerned with vegetation analysis in the SSZ, as reflected by the variety of journals used for publication.

- The geographical distribution of the RS research is uneven in the SSZ, with a dominance within a few countries (e.g., Burkina Faso, Niger and Senegal). Potential factors for this pattern include multilateral research collaborations, availability of in situ data and research infrastructure, and political stability.

- African lead- and co-authors are underrepresented in the literature, suggesting that RS research in the SSZ has largely been dependent on resources (expertise and financing) from developed countries in Europe and North America.

- In the SSZ, RS has primarily been used to analyze vegetation change as an effect of different types of disturbance, whereas its use in research about relationship to environmental factors, such as rainfall, soil properties, groundwater and terrain, has been relatively limited. 
- A few vegetation variables, namely vegetation productivity and broad vegetation types, have dominated the research where RS has been applied in the SSZ. Important topics for future RS research therefore includes improved vegetation mapping of morphological structure of woody vegetation and floristic composition at spatial scales relevant for both research and natural resource management applications.

\section{Acknowledgements}

The work has been funded by the Swedish International Development Cooperation Agency (Sida), the Swedish Energy Agency and the Swedish Research Council (VR/Sida). The authors thank Heather Reese, Tina Neset, David Bastviken, Åsa Danielsson and Rasmus Fensholt for valuable input to the manuscript. The anonymous reviewers are thanked for fruitful comments that helped improving the paper.

\section{References}

Abiodun, A.A. 2000. Development and utilization of remote sensing technology in Africa. Photogrammetric Engineering \& Remote Sensing June: 674-686.

Anyamba, A., and C.J. Tucker. 2005. Analysis of Sahelian vegetation dynamics using NOAA-AVHRR NDVI data from 1981-2003. Journal of Arid Environments 63: 596-614.

Bailis, R., M. Ezzati, and D. Kammen. 2005. Mortality and greenhouse gas impacts of biomass and petroleum energy futures in Africa. Science 308: 98-103.

Bargués Tobella, A., H. Reese, A. Almaw, J. Bayala, A. Malmer, H. Laudon, and U. Ilstedt. 2014. The effect of trees on preferential flow and soil infiltrability in an agroforestry parkland in semiarid Burkina Faso, Water Resources Research 50: 3342-3354.

Batterbury, S., and A. Warren. 2001. The African Sahel 25 years after the great drought: assessing progress and moving towards new agendas and approaches. Global Environmental Change 11:1-8.

Bayala, J., A. Mando, Z. Teklehaimanot, and S.J. Ouendraogo. 2005. Nutrient release from decomposing leaf mulches of karate (Vitellaria paradoxa) and néré (Parkina biglobosa) under semi-arid conditions in Burkina Faso, West Africa. Soil biology and biochemistry 37: 533539.

Boffa, J.M. 1999. Agroforestry parkland in Sub-Saharan Africa: FAO conservation guide 34. Rome, Italy: Food and Agriculture Organization of the United Nations.

Brandt, M., A. Verger, A.A. Diouf, F. Baret, and C. Samimi. 2014a. Local vegetation trends in the Sahel of Mali and Senegal using long time series FAPAR satellite products and field measurement (1982-2010). Remote Sensing 6: 2408-2434.

Brandt, M., C. Romankiewicz, R. Spiekermann, C. Samimi. 2014b. Environmental change in time series: An interdisciplinary study in the Sahel of Mali and Senegal. Journal of Arid Environments 105: 52-63. 
Brandt, M., C. Mbow, A.A. Diouf, A. Verger, C. Samimi, and R. Fensholt. 2015. Groundand satellite-based evidence of biophysical mechanisms behind the greening Sahel. Global Change Biology 21: 1610-1620.

Brink, A.B., and H.D. Eva. 2011. The potential use of high-resolution Landsat satellite data for detecting land-cover change in the Greater Horn of Africa. International Journal of Remote Sensing 32: 5981-5995.

Charney, J.G. 1975. Dynamics of Deserts and Drought in Sahel. Quarterly Journal of the Royal Meteorological Society 101: 193-202.

Cord, A., C. Conrad, M. Schmidt, and S. Dech. 2010. Standardized FAO-LCCS land cover mapping in heterogeneous savannas of West Africa. Journal of Arid Environments 74: 10831091.

DeFries, R. 2008. Terrestrial vegetation in the coupled human-earth system: Contributions of remote sensing. Annual Review of Environment and Resources 33: 369-390.

Diouf, A., and E.F. Lambin. 2001. Monitoring land-cover changes in semi-arid regions: remote sensing data and field observations in the Ferlo, Senegal. Journal of Arid Environments 48: 129-148.

Drusch, M., U. Del Bello, S. Carlier, O. Colin, V. Fernandez, F. Gascon, B. Hoersch, C. Isola, P. Laberinti, P. Martimort, A. Meygret, F. Spoto, O. Sy, F. Marchese, and P. Bargellini. 2012. Sentinel-2: ESA's Optical High-Resolution Mission for GMES Operational Services. Remote Sensing of Environment 120: 25-36.

Eisenfelder, C., C. Kuenzer, and S. Dech. 2012. Derivation of biomass information for semiarid areas using remote sensing data. International Journal of Remote Sensing 33: 2937-2984.

Fairhead J.,and M. Leach. 1995. False forest history, complicit social analysis: rethinking some West African environmental narratives. World Development 23: 1023-1035.

Fensholt, R., and S.R. Proud. 2012. Evaluation of earth observation based global long term vegetation trends - Comparing GIMMS and MODIS global NDVI time series. Remote Sensing of Environment 199: 131-147.

Fensholt, R., and K. Rasmussen. 2011. Analysis of trends in the Sahelian 'rain-use efficiency' using GIMMS NDVI, RFE and GPCP rainfall data. Remote Sensing of Environment 115: 438-451

Fensholt, R., I. Sandholt, and M.S Rasmussen. 2004. Evaluation of MODIS LAI, fAPAR and the relation between fAPAR and NDVI in a semi-arid environment using in situ measurements. Remote Sensing of Environment 91: 490-507.

Fensholt, R., K. Rasmussen, T.T. Nielsen, and C. Mbow. 2009. Evaluation of earth observation based long term vegetation trends - Intercomparing NDVI time series trend analysis consistency of Sahel from AVHRR GIMMS, Terra MODIS and SPOT VGT data. Remote Sensing of Environment 113: 1886-1898.

[Skriv här] 
Fensholt, R., K. Rasmussen, P. Kaspersen, S. Huber, S. Horion, and E. Swinnen. 2013. Assessing Land Degradation/Recovery in the African Sahel from Long-Term Earth Observation Based Primary Productivity and Precipitation Relationships. Remote Sensing 5: 644-686.

Fensholt, R., I. Sandholt, M.S. Rasmussen, S. Stisen, and A. Diouf. 2006. Evaluation of satellite based primary productions modelling in the semi-arid Sahel. Remote Sensing of Environment 105: 173-188.

Franklin, J. 1991. Land cover stratification using Landsat Thematic Mapper data in Sahelian and Sudanian woodland and wooded grassland. Journal of Arid Environments 20: 141-163.

Giannini, A., S. Salack, T. Lodoun, A. Ali, A. T. Gaye and O. Ndiaye. 2013. A unifying view of climate change in the Sahel linking intra-seasonal, interannual and longer time scales. Environmental Research Letters 8: 024010.

Gnankambary, Z., J. Bayala, A. Malmer, G. Nyberg, and V. Hien. 2008. Decomposition and nutrient release from mixed plant litters of contrasting quality in an agroforestry parkland in the south-Sudanese zone of West Africa. Nutrient Cycling in Agroecosystems 82: 1-13.

Gonzalez, P. 2001. Desertification and a shift of forest species in the West African Sahel. Climate research 17: 217-228.

Gonzalez, P., C.J. Tucker, and H. Sy. 2012. Tree density and species decline in the African Sahel attributable to climate. Journal of Arid Environments 78: 55-64

Gough, D., Oliver, S., Thomas, J., 2012. An Introduction to Systematic Reviews. SAGE Publications, London.

Goutorbe, J.P., T. Lebel, A.J. Dolman, J.H. Gash, P. Kabat, Y.H Kerr, B. Monteny, et al. 1997. An overview of HAPEX-SAHEL: a study in climate and desertification. Journal of Hydrology 188-189: 4-17.

Hansen, M.C., R.S. DeFries, J.R.G. Townshend, M. Carroll, C. Dimiceli, and R.A Sohlberg. 2003. Global percent tree cover at a spatial resolution of 500 meters: First results of the MODIS vegetation continuous fields algorithm. Earth Interactions 7: 1-15.

Helldén, U. 1991. Desertification - Time for an assessment? Ambio 20: 372-383.

Herrmann, S.M., and C.F. Hutchinson. 2005. The changing contexts of the desertification debate. Journal of Arid Environments 63: 538-555.

Herrmann, S.M., A. Anyamba, and C.J. Tucker. 2005. Recent trends in vegetation dynamics in the African Sahel and their relationship to climate. Global Environmental Change 15: 394404.

Herrmann, S.M., and G.G. Tappan. 2013. Vegetation impoverishment despite greening: A case study from central Senegal. Journal of Arid Environments 90: 55-66. 
Herrmann, S. M., I. Sall, and O. Sy. 2014. People and pixels in the Sahel: a study linking coarse-resolution remote sensing observations to land users' perceptions of their changing environment in Senegal. Ecology and Society 19: 29.

Hiernaux, P., L. Diarra, V. Trichon, E. Mougin, N. Soumaguel, and F. Baup. 2009. Woody plant population dynamics in response to climate changes from 1984 to 2006 in Sahel (Gourma, Mali). Journal of Hydrology 375: 103-113.

Hijmans, R.J., S.E. Cameron, J.L. Parra, P.G. Jones and A. Jarvis, 2005. Very high resolution interpolated climate surfaces for global land areas. International Journal of Climatology 25: 1965-1978.

Horion, S., R. Fensholt, T. Tagesson, and A. Ehammer. 2014. Using earth observation-based dry season NDVI trends for assessment of changes in tree cover in the Sahel, International Journal of Remote Sensing 35: 2493-2515. (C-TCP)

Hulme, M., R. Doherty, T. Ngara, M. New, and D. Lister. 2001. African climate change:1900-2100. Climate Research 17: 145-168.

Ilstedt, U., A. Malmer, E. Verbeeten, and D. Murdiyarso. 2007. The effect of afforestation on water infiltration in the tropics: A systematic review and meta-analysis. Forest Ecology and Management 251: 45-51.

Kammerud, T.A. 1996. Soil impact on satellite based vegetation monitoring in Sahelian Mali. Geografiska Annaler. Series A, Physical Geography 78: 247-259.

Karlson, M., M. Ostwald, H. Reese, J. Sanou, B. Tankoano, and E. Mattsson. 2015. Mapping tree canopy cover and aboveground biomass in Sudano-Sahelian woodlands using Landsat 8 and Random Forest. Remote Sensing 7: 10017-10041.

Kelder, Y., T.T. Nielsen, and R. Fensholt. 2013. The Role of Methodology and Spatiotemporal Scale in Understanding Environmental Change in Peri-Urban Ouagadougou, Burkina Faso. Remote Sensing 5: 1465-1483.

Kergoat, L., M. Grippa, A. Baille, L. Eymard, R. Lacaze, E. Mougin, C. Ottlé, et al. 2011. Remote sensing of the land surface during the African Monsoon Multidisciplinary Analysis (AMMA). Atmospheric Science Letters 12: 129-134.

Knauer, K., U. Gessner, S. Dech, and C. Kuenzer. 2014. Remote sensing of vegetation dynamics in West Africa. International Journal of Remote Sensing 35: 6357-6396.

Lambin, E.F. 1999. Monitoring forest degradation in tropical regions by remote sensing: some methodological issues. Global Ecology and Biogeography 8:191-198.

Lamprey, H.F. 1975. Report on the Desert Encroachment Reconnaissance in Northern Sudan. Report to the United Nations Environment Program, Bailis Bailis Bailis, New York.

Lebel, T., and A. Ali. 2009. Recent trends in the Central and Western Sahel rainfall regime (1990-2007). Journal of Hydrology 375: 52-64. 
Le Houéron, H.N. 1980. The rangelands of the Sahel."Journal of Range Management 33: 4146.

Le Houérou H.N. 1989. The grazing land ecosystems of the African Sahel. Springer-Verlag, Berlin, 282pp.

Leprieur, C., Y.H. Kerr, S. Mastorchio, and J.C. Meunier. 2000. Monitoring vegetation cover across semi-arid regions: comparison of remote observations from various scales.

International Journal of Remote Sensing 21: 281-300.

Manning, A.D., P. Gibbons, and D.B. Lindenmayer. 2009. Scattered trees: A complementary strategy for facilitating adaptive responses to climate change in modified landscapes? Journal of Applied Ecology 46: 915-919.

Maranz, S. 2009. Tree mortality in the African Sahel indicates an anthropogenic ecosystem displaced by climate change. Journal of Biogeography 36: 1181-1193.

Mbow, C., R. Fensholt, T. Theis Nielsen, and K. Rasmussen. 2014. Advances in monitoring vegetation and land use dynamics in the Sahel. Danish Journal of Geography 114: 84-91.

Mbow, C., M. Brandt, I. Ouédraogo, J. De Leeuw, and M. Marshall. 2015. What Four Decades of Earth Observation Tell Us about Land Degradation in the Sahel? Remote Sensing 7: 4048-4067.

Mertz, O., S. D’haen, A. Maiga, I.B. Moussa, B. Barbier, A. Diouf, D. Diallo, E.D. Da, et al. 2012. Climate variability and environmental stress in the Sudan-Sahel zone of West Africa. Ambio 41: 380-392.

Milich, L., and E. Weiss. 2000. GAC NDVI interannual coefficient of variation (CoV) images: ground truth sampling of the Sahel along north-south transects. International Journal of Remote Sensing 21: 235-260

Mitchard, E.T.A. and C.M. Flintrop. 2013. Woody encroachment and forest degradation in sub-Saharan Africa's woodlands and savannas 1982-2006. Philosophical Transactions of the Royal Society 368: 20120406.

Mougin, E., P. Hiernaux, L. Kergoat, M. Grippa, P. de Rosnay, F. Timouk, V.Le Dantec, et al. 2009. The AMMA-CATCH Gourma observatory site in Mali: Relating climatic variations to changes in vegetation, surface hydrology, fluxes and natural resources. Journal of Hydrology 375: 14-33.

Nicholson, S. 1995. Sahel, West Africa. In: Encyclopedia of Environmental Biology, vol. 3, edited by Nierenberg, W.A, 261-275. San Diego, CA: Academic Press.

Nicholson, S.E. 2001. Climatic and environmental change in Africa during the last two centuries. Climate Research 17: 123-144.

Nicholson, S.E. 2009. A revised picture of the structure of the "monsoon" and land ITCZ over West Africa. Climate Dynamics 32: 1155-1171. 
Nicholson, S. E. 2013. The West African Sahel: a review of recent studies on the rainfall regime and its interannual variability. ISRN Meteorology 2013: 453521.

Oduolowu, I.A. 1977. Qualitative interpretation of remotely sensored data as a key to mapping vegetation patterns in the western Sudan. GeoJournal 1: 13-20. (A-VT)

Olsson, L., L. Eklundh, and J. Ardö. 2005. A recent greening of the Sahel - trends, patterns and potential causes. Journal of Arid Environments 63: 556-566.

Pettorelli, N., K. Safi, and W. Turner. 2014. Satellite remote sensing, biodiversity research and conservation of the future. Philosophical Transactions of the Royal Society - B 369: 20130190.

Philippon, N., E. Mougin, L. Jarlan, and P. Frison. 2005. Analysis of the linkages between rainfall and land surface conditions in the West African monsoon through CMAP, ERSWSC, and NOAA-AVHRR data. Journal of Geophysical Research 110: D24115.

Potts, M., Zulu, E., Wehner, M., Castillo, F. and Henderson, C. 2013. Crisis in the Sahel, possible solutions and the consequences of inaction. A report following the OASIS Conference (Organizing to Advance Solutions in the Sahel) hosted by the University of California, Berkeley and African Institute for Development Policy in Berkeley on September 21, 2012.

Prince, S.D., and Justice, C.O. (editors), 1991, Coarse resolution remote sensing of the Sahelian environment. International Journal of Remote Sensing, 12, 1133-1421.

Rasmussen, K., R. Fensholt, B. Fog, L. Vang Rasmussen, and I. Yanogo. 2014. Explaining NDVI trends in northern Burkina Faso. Danish Journal of Geography 114: 17-24.

Rembold, F., S.M. Oduori, H. Gadain, P. Toselli. 2013. Mapping charcoal driven forest degradation during the main period of Al Shabaab control in Southern Somalia. Energy for Sustainable Development 17: 510-514.

Romijn, E., M. Herold, L. Kooistra, D. Murdiyarso, and L. Verchot. 2012. Assessing capacities of non-Annex I countries for national forest monitoring in the context of REDD+. Environmental Science and Policy 19-20: 33-48.

Roy, D.P., J. Ju, C. Mbow, and T. Loveland. 2010. Accessing free Landsat data via the Internet: Africa's challenge. Remote Sensing Letters 1: 111-117.

Ruelland, D., A. Dezetter, C. Puech, and S. Ardoin-Bardin. 2008. Long-term monitoring of land cover changes based on Landsat imagery to improve hydrological modeling in West Africa. International Journal of Remote Sensing 29: 3533-3551.

Ruelland, D., F. Levavasseur, and A. Tribotté. 2010. Patterns and dynamics of land-cover changes since the 1960s over three experimental areas in Mali. International Journal of Applied Earth Observation and Geoinformation 125: S11-S17. 
Saatchi, S.S., N.L. Harris, S. Brown, M. Lefsky, E.T.A. Mitchard, W. Salas, B.R. Zutta, et al. 2011. Benchmark map of forest carbon stocks in tropical regions across three continents. Proceeding of the National Academy of Sciences of the United States of America 108: 98999904.

Sexton, J.O., X.P. Song, M. Feng, P. Moojipady, A. Anand, C. Huang, D.O. Kim, K.M. Collins, S. Channan, C. DeMiceli, and J.R. Townsend. 2013. Global, 30-m resolution continuous field of tree cover: Landsat-based rescaling of MODIS vegetation continuous fields with lidar-based estimates of error. International Journal of Digital Earth 6: 427-448.

Sinare, H., and L. Gordon. 2015. Ecosystem services from woody vegetation on agricultural lands in Sudano-Sahelian West Africa. Agriculture, Ecosystems and Environment 200: 186199.

Sjöström, M., J. Ardö, L. Eklundh, B.A. El-Tahir, H.A. El-Khidir, M. Hellström, P. Pilesjö, and J. Seaquist. 2009. Evaluation of satellite based indices for gross primary production estimates in a sparse savanna in the Sudan. Biogeosciences 6: 129-138.

Sjöström, M., J. Ardö, A. Arneth, N. Boulin, B. Cappelaere, L. Eklundh, A. de Grandcourt, et al. 2011. Exploring the potential of MODIS EVI for modelling gross primary production across African ecosystems. Remote Sensing of Environment 115: 1081-1089.

Sjöström, M., M. Zhao, S. Archibald, A. Arneth, B. Cappelaere, U. Falk, A. de Grandcourt, N.P. Hanan, L. Kergoat, W. Kutsch, L. Merbold, E. Mougin, A. Nickless, Y. Nouvellon, R.J. Scholes, E.M. Veenendaal, and J. Ardö. 2013. Evaluation of MODIS gross primary productivity for Africa using eddy covariance data. Remote Sensing of Environment 131: 275-286.

Tagesson, T., R. Fensholt, I. Guiro, M.O. Rasmussen, S. Huber, C. Mbow, M. Garcia, S. Horion, I. Sandholt, B. Holm-Rasmussen, F. Göttsche, M.E., Ridler, N. Olén, J. Lundegard, A Ehammer, M. Madsen, F.S. Olesen, and J. Ardö. 2014. Ecosystem properties of semiarid savanna grassland in West Africa and its relationship with environmental variability. Global Change Biology 21, doi: 10.1111/gcb.12734 250-264.

Tappan, G.G., A. Hadj, E.C. Wood, and R.W. Lietzow. 2000. Use of Argon, Corona and Landsat imagery to assess 30 years of land resource changes in west-central Senegal. Photogrammetric Engineering and Remote Sensing 66: 727-735.

Tappan, G.G., M. Sall, E.C. Wood, and M. Cushing. 2004. Ecoregions and land cover trends in Senegal. Journal of Arid Environments 59: 427-462.

Thomas, D.S.G., and N.J. Middleton. 1994. Desertification: Exploding the myth. Wiley, 194 pp.

Tschakert, P., R. Sagoe, G. Ofori-Darko, and S.N. Codjoe. 2010. Floods in the Sahel: an analysis of anomalies, memory, and anticipatory learning. Climatic Change 103: 471-502. 
Thomas, D.S.G. and N.J. Middleton. 1994. Desertification: Exploding the myth. Wiley, 194 pp.

Tucker, C.J., H.E. Dregne, and W.W. Newcomb. 1991. Expansion and contraction of the Sahara desert from 1980 to 1990. Science 253: 299-301.

Tucker, C.J., and S.E. Nicholson. 1999. Variations in the size of the Sahara desert from 1980 to 1997. Ambio 28: 587-591.

Turner, M.D. 2003. Methodological reflections on the use of remote sensing and geographic information science in human ecological research. Human Ecology 31: 255-279.

UN (United Nations). 1994. United Nations Convention to Combat Desertification in Countries Experiencing Serious Drought and/or Desertification, Particularly in Africa. Document A/AC. 241/27, 12. 09. 1994 with Annexes, United Nations: New York, NY.

UNCCD (United Nations Convention to Combat Desertification). 2014. Accessed February 20. http://www.unccd.int/en/about-the-convention/Pages/Text-Part-I.aspx

UNEP (United Nations Environmental Programme). 2011. Livelihood security. Climate change, migration and conflict in the Sahel. Geneva: United Nations Environment Programme.

Ustin, S.L., and J.A. Gamon. 2010. Remote sensing of plant functional types. New Phytologist 186: 795-816.

Van der Maarel, E.2005. Vegetation Ecology. (Ed) London, United Kingdom: Blackwell Science Ltd.

Van Leeuwen, W.J., A.R. Huete, J. Duncan, and J. Franklin. 1994. Radiative transfer in shrub savanna sites in Niger: preliminary results from HAPEX-Sahel. 3. Optical dynamics and vegetation index sensitivity to biomass and plant cover. Agricultural and Forest Meteorology 69: 267-288.

Vittek, M., A. Brink, F. Donnay, D. Simonetti, and B. Desclée. 2014. Land Cover Change Monitoring Using Landsat MSS/TM Satellite Image Data over West Africa between 1975 and 1990. Remote Sensing 6: 658-676.

Wezel, A., and T. Rath. 2002. Resource conservation strategies in agro-ecosystems of semiarid West Africa. Journal of Arid Environments 51: 383-400.

White, F. 1983. Vegetation of Africa - a descriptive memoir to accompany the Unesco/AETFAT/UNSO vegetation map of Africa; Natural Resources Research Report XX. Paris, France: United Nations Educational, Scientific and Cultural Organization.

Woldai T., and H. Annegarn. 2010. Remote sensing for Africa: a special collection from the African Association for Remote Sensing of the Environment. International Journal of Applied Earth Observation and Geoinformation: JAG 12(Suppl. 1): S1-S2. 
Wu, W., E. De Pauw, and U. Helldén. 2013. Assessing woody biomass in African tropical savannahs by multiscale remote sensing. International Journal of Remote Sensing 34: 45254549.

Zeng, N. 2003. Drought in the Sahel. Science 302: 999-1000. 


\section{Electronic supplementary material}

This is a list of all articles $(n=268)$ included in the literature review. The articles are grouped into the three main categories, which are based on the research topic. References in italic are included in two of the main categories. An interpretation key is provided for each category.

\section{Vegetation mapping}

Key: DE (data evaluation), LAI (leaf area index), PP (primary production), T (transpiration), TCP (tree cover properties), VT (vegetation type) WC (water content)

Aynekulu, E., T. Kassawmar, and L. Tamene. 2008. Applicability of ASTER imagery in mapping land use / cover as a basis for biodiversity studies in drylands of northern Ethiopia. African Journal of Ecology 46 (Suppl 1): 19-23. (VT)

Bèniè, G.B., S.S. Kaboré, K. Goita, and M.F. Courel. 2005. Remote sensing-based spatiotemporal modeling to predict biomass in Sahelian grazing ecosystems. Ecological Modelling, 184: 341-354. (PP)

Biro, K., B. Pradhan, H. Sulieman, and M. Buchroithner. 2013. Exploitation of TerraSAR-X data for land use/land cover analysis using object-oriented classification approach in the African Sahel area, Sudan. Journal of the Indian Society of Remote Sensing 41: 539-553. (VT)

Boegh, E., H. Soegaard, N.P. Hanan, P. Kabat, and L. Lesch. 1999. A remote sensing study of the NDVI- $T_{\mathrm{s}}$ relationship and the transpiration from sparse vegetation in the Sahel based on high-resolution satellite data. Remote Sensing of Environment 69: 224-240. (T)

Ceccato, P., N. Gobron, S. Flasse, B. Pinty, and S. Tarantola. 2002. Designing a spectra index to estimate vegetation water content from remote sensing data: Part 1 theoretical approach. Remote Sensing of Environment 82: 188-197. (WC)

Ceccato, P., S. Flasse, and J.M. Grégoire. 2002. Designing a spectra index to estimate vegetation water content from remote sensing data: Part 2 Validation and applications. Remote Sensing of Environment 82: 198-207. (WC)

Cord, A., C. Conrad, M. Schmidt, and S. Dech. 2010. Standardized FAO-LCCS land cover mapping in heterogeneous savannas of West Africa. Journal of Arid Environments 74: 10831091. (VT)

Couteron, P., M. Deshayes, and C. Roches. 2001. A flexible approach for woody cover assessment from SPOT HRV XS data in semi-arid West Africa. Application in northern Burkina Faso. International Journal of Remote Sensing 22: 1029-1051. (TCP)

Dardel, C., L. Kergoat, P. Hiernaux, E. Mougin, M. Grippa, and C.J. Tucker. 2014. Regreening Sahel: 30 years of remote sensing data and field observations (Mali, Niger). Remote Sensing of Environment 140: 350-364. (DE)

Defourny, P. 1991. Multistage and multisensor approach for woody biomass evaluation in a tree savanna region (Burkina Faso). IEEE 4: 2461-2464. (TCP) 
Devineau, J-P., Aurouet, A., Douanio, M., Hladik, A. 2008. Changes in the availability and uses of wild yams according to climatic dryness and land-cover in Western Burkina Faso (West Africa): a joint ecological and ethno-botanical approach using GIS and remote-sensing. Biodiversity and Conservation 17: 1937-1963. (VT)

Diallo, O., A. Diouf, N.P. Hanan, A. Ndiaye, and Y. Prévost. 1991. AVHRR monitoring of savanna primary production in Senegal, West Africa: 1987-1988. International Journal of Remote Sensing 12: 1259-1279. (PP)

Djaroudib, K. 1993. Quantitative estimation of woody vegetation in the Sudano-Sahelian region. A textural approach applied in a region of Burkina Faso. EARSeL Advances in Remote Sensing 2: 56-63. (TCP)

Egziabher, T.B., E. Feoli, M. Fernetti, G. Oiolo, and Z. Woldu. 1998. Vegetation mapping by intergration of floristic analysis, GIS and remote sensing. An example for Tigray (Ethiopia). Plant Biosystems 132: 39-51. (VT)

Fensholt, R. 2004. Earth observation of vegetation status in the Sahelian and Sudanian West Africa: comparison of Terra MODIS and NOAA AVHRR satellite data. International Journal of Remote Sensing 25:1641-1659. (DE)

Fensholt, R., I. Sandholt, and M.S Rasmussen. 2004. Evaluation of MODIS LAI, fAPAR and the relation between $F A P A R$ and NDVI in a semi-arid environment using in situ measurements. Remote Sensing of Environment 91: 490-507. (PP + LAI)

Fensholt, R., B. Anyamba, S. Huber, S.R. Proud, C.J. Tucker, J. Small, E. Pak, M.O. Rasmussen, I. Sandholt, and C. Shisanya. 2011. Analysing the advantages of high temporal resolution geostationary MSG SEVIRI data compared to Polar operational environmental satellite data for land surface monitoring in Africa. International Journal of Applied Earth Observation and Geoinformation 13: 721-729. (DE)

Fensholt, R., S. Huber, S.R. Proud, and C. Mbow. 2010. Detecting canopy water status using shortwave infrared reflectance data from polar orbiting and geostationary platforms. IEEE Journal of Selected Topics in Applied Earth Observations and Remote Sensing 3: 271-285. (WC)

Fensholt, R., and S.R. Proud. 2012. Evaluation of earth observation based global long term vegetation trends-Comparing GIMMS and MODIS global NDVI time series. Remote Sensing of Environment 199: 131-147. (DE)

Fensholt, R. and I. Sandholt. 2003. Derivation of a shortwave infrared water stress index from MODIS near- and shortwave infrared data in a semiarid environment. Remote Sensing of Environment 87: 111- 121. (WC)

Fensholt, R., I. Sandholt, M.S. Rasmussen, S. Stisen, and A. Diouf. 2006. Evaluation of satellite based primary productions modelling in the semi-arid Sahel. Remote Sensing of Environment 105: 173-188. (PP)

Fensholt, R., A. Anyamba, S. Stisen, I. Sandholt, E. Pak, and J. Small. 2007. Comparisons of compositing period length for vegetation index data from polar-orbiting and geostationary 
satellites for the cloud-prone region of West Africa. Photogrammetric Engineering \& Remote Sensing 73: 297-309. (DE)

Fensholt, R., I. Sandholt, and S. Stisen. 2006. Evaluating MODIS, MERIS, and VEGETATION vegetation indices using in situ measurements in a semiarid environment. IEEE Transactions on Geoscience and Remote Sensing 44: 1774-1786. (DE)

Fensholt, R., and I. Sandholt. 2005. Evaluation of MODIS and NOAA AVHRR vegetation indices with in situ measurements in a semi-arid environment. International Journal of Remote Sensing 26: 2561-2594. (DE)

Fensholt, R., A. Anyamba, S. Huber, S.R. Proud, C.J. Tucker, J. Small, E. Pak, M.O. Rasmussen, I. Sandholt, C. Shisanya. 2011. Analysing the advantages of high temporal resolution geostationary MSG SEVIRI data compared to Polar Operational Environmental Satellite data for land surface monitoring in Africa. International Journal of Applied Earth Observation and Geoinformation 13: 721-729. (DE)

Fensholt, R., K. Rasmussen, T.T. Nielsen, and C. Mbow. 2009. Evaluation of earth observation based long term vegetation trends - Intercomparing NDVI time series trend analysis consistency of Sahel from AVHRR GIMMS, Terra MODIS and SPOT VGT data. Remote Sensing of Environment 113: 1886-1898. (DE)

Fensholt, R., I. Sandholt, S.R. Proud, S. Stisen, and M.O. Rasmussen. 2010. Assessment of MODIS sun-sensor geometry variations effect on observed NDVI using MSG SEVIRI geostationary data, International Journal of Remote Sensing 31: 6163-6187. (DE)

Franklin, J. 1991. Land cover stratification using Landsat Thematic Mapper data in Sahelian and Sudanian woodland and wooded grassland. Journal of Arid Environments 20: 141-163. (VT)

Franklin, J., and P. Hiernaux. 1991. Estimating foliage and woody biomass in Sahelian and Sudanian woodlands using a remote sensing model. International Journal of Remote Sensing 12: 1387-1404. (TCP)

Franklin, J., and A.H. Strahler. 1988. Invertible canopy reflectance modeling of vegetation structure in semiarid woodland. IEEE Transactions on Geoscience and Remote Sensing 26: 809-825. (TCP)

Frederiksen, P., and J.E. Lawesson. 1992. Vegetation types and patterns in Senegal based on multivariate analysis of field and NOAAAVHRR satellite data. Journal of Vegetation Science 3: 535-544. (VT)

Frison, P., E. Mougin, and P. Hiernaux. 1998. Observations and interpretation of seasonal ERS-1 Wind Scatterometer Data over northern Mali. Remote Sensing of Environment 63: 233-242. (PP)

Frison, P.L., E. Mougin, L. Jarlan, M.A. Karam, and P. Hiernaux. 2000. Comparison of ERS Wind-Scatterometer and SSM/I data for Sahelian vegetation mapping. IEEE Transactions on geosciences and remote sensing 38: 1794-1803. (PP) 
Frison, P.L., G. Mercier, G. Faye, E. Mougin, P. Hiernaux, C. Lardeux, and J.P. Rudant. 2013. Analysis of L- and C-band SAR image time series over a Sahelian area. IEEE Geoscience and Remote Sensing Letters 10: 1016-1020. (PP)

García, M., I. Sandholt, P. Ceccato, M. Ridler, E.Mougin, L. Kergoat, L.Morillas, F. Timouk, R. Fensholt, and F. Domingo. 2013. Actual evapotranspiration in drylands derived from insitu and satellite data: Assessing biophysical constraints. Remote Sensing of Environment 131: 103-118. (T)

Gilabert, M.A., F. Maselli, C. Conese, and M. Bindi. 1995. Characterization of primary productivity levels of Niger by means of NOAA NDVI variations. Geocarto International 10: 31-41. (VT)

Grippa, M., and I.H. Woodhouse. 2002. Retrieval of bare soil and vegetation parameters from wind scatterometer measurements over three different climatic regions. Remote Sensing of Environment 84: 16-24. (VT)

Groten, S.M.E. and R. Ocatre. 2002. Monitoring the length of the growing season with NOAA. International Journal of Remote Sensing 23: 2797-2815. (P)

Hanan, N.P., S.D. Prince, and A. Bégué. 1995. Estimation of absorbed photosynthetically active radiation and vegetation net production efficiency using satellite data. Agricultural and Forest Meteorology 76: 259-276. (PP)

Herrmann, S.M., A.J. Wickhorst, and S.E. Marsh. 2013. Estimation of Tree Cover in an Agricultural Parkland of Senegal Using Rule-Based Regression Tree Modeling. Remote Sensing 5: 4900-4918. (TCP)

Hielkema, J.U., J. Roffey, and C.J. Tucker. 1986. Assessment of ecological conditions associated with the 1980/81 desert locust plague upsurge in West Africa using environmental satellite data. International Journal of Remote Sensing 7 (11): 1609-1622. (PP)

Huber, S., T. Tagesson, and R. Fensholt. 2014. An automated field spectrometer system for studying VIS, NIR and SWIR anisotropy for semi-arid savanna. Remote Sensing of Environment 152: 547-556. (DE)

Jacques, D.C., L. Kergoat, P. Hiernaux, E. Mougin, and P. Defourny. 2014. Monitoring dry vegetation masses in semi-arid areas with MODIS SWIR bands. Remote Sensing of Environment 153: 40-49. (PP)

Jarlan, L., E. Mougin, P.L. Frison, P. Mazzega, and P. Hiernaux. 2002. Analysis of ERS wind scatterometer timeseries over Sahel (Mali). Remote Sensing of Environment 81: 404-415. (PP)

Jarlan, L., P. Mazzega, and E. Mougin. 2002. Retrieval of land surface parameters in the Sahel frpm ERS Wind Scatterometer data: A "brute force" method. IEEE Transactions on Geoscience and Remote Sensing 40: 2056-2062. (PP) 
Jarlan, L., P. Mazzega, E. Mougin, F. Lavenu, G. Marty, P.L Frison, and P. Hiernaux. 2003. Mapping of Sahelian vegetation parameters from ERS scatterometer data with an evolution strategies algorithm. Remote Sensing of Environment 87: 72-84. (PP)

Jarlan, L., Mougin, E., Mazzega, P., Schoenauer, M., Tracol, Y. and Hiernaux, P. 2005. Using coarse remote sensing radar observations to control the trajectory of a simple Sahelian land surface model. Remote Sensing of Environment 94: 269-285. (PP)

Jarlan, L., S. Mangiarotti, E. Mougin, P. Mazzega, P. Hiernaux, and V. Le Dantec. 2008. Assimilation of SPOT/VEGETATION NDVI data into a sahelian vegetation dynamics model. Remote Sensing of Environment 112: 1381-1394. (PP)

Justice, C.O., and P. Hiernaux. 1986. Monitoring the grasslands of Sahel using NOAA AVHRR data: Niger 1983. International Journal of Remote Sensing 7: 1475-1497. (PP)

Kammerud, T.A. 1996. Soil impact on satellite based vegetation monitoring in Sahelian Mali. Geografiska Annaler. Series A, Physical Geography 78: 247-259. (DE)

Karlson, M., H. Reese, and M. Ostwald. 2014. Tree crown mapping in managed woodlands (parklands) of semi-arid West Africa using WorldView-2 imagery and geographic object based image analysis. Sensors 14: 22643-22669. (TCP)

Larsson, H. 1993. Linear regressions for canopy cover estimation in Acacia woodlands using Landsat-TM, -MSS and SPOT HRV XS data. International Journal of Remote Sensing 14: 2129-2136. (TCP)

Leprieur, C., Y.H. Kerr, S. Mastorchio, and J.C. Meunier. 2000. Monitoring vegetation cover across semi-arid regions: comparison of remote observations from various scales. International Journal of Remote Sensing 21: 281-300. (PP)

Lind, M., and R. Fensholt. 1999. The spatio-temporal relationship between rainfall and vegetation development in Burkina Faso. Danish Journal of Geography 2: 43-55. (PP)

Lindström, J., L. Eklundh, J. Holst, and U. Holst. 2006. Influence of solar zenith angles on observed trends in the NOAA/NASA 8-km Pathfinder normalized difference vegetation index over the African Sahel. International Journal of Remote Sensing 27: 1973-1991. (DE)

Lo Sheen, D., E. Mougin, S. Rambal, A. Gaston, and P. Hiernaux. 1995. A regional Sahelian grassland model to be coupled with multispectral satellite data. II: Toward the control of its simulations by remotely sensed indices. Remote Sensing of Environment 52: 194-206. (PP)

Luafafa, A., J. Bolte, D. Wright, M. Khouma, I. Diedhiou, R.P Dick, F. Kizito, E. Dossa, and J.S. Noller. 2008. Regional carbon stocks and dynamics in native woody shrub communities of Senegals Peanut Basin. Agriculture, Ecosystems and Environment 128: 1-11. (TCP)

Madsen, J.E., M. Lind, and B. Fog. 1999. Accuracy of aerial photos for recognizing trees in West African cultural landscapes. Danish Journal of Geography 2: 139-148. (TCP) 
Mangiarotti, S., Mazzega, P., Jarlan, L., Mougin, E., Baup, F. and Demarty, J. 2008.

Evolutionary bi-objective optimization of a semi-arid vegetation dynamics model with NDVI and $\sigma 0$ satellite data. Remote Sensing of Environment 112: 1365-1380. (PP)

Mangiarotti, S., P. Mazzega, P. Hiernaux, and E. Mougin. 2010. The vegetation cycle in West Africa from AVHRR-NDVI data: Horizons of predictability versus spatial scales. Remote Sensing of Environment 114: 2036-2047. (PP)

Mangiarotti, S., P. Mazzega, P. Hiernaux, and E. Mougin. 2012. Predictability of vegetation cycles over the semi-arid region of Gourma (Mali) from forecasts of AVHRR-NDVI signals. Remote Sensing of Environment 123: 246-257. (PP)

Marshall, M., K. Tu, C. Funk, J. Michaelsen, P. Williams, C. Williams, J. Ardö, M. Boucher, B. Cappelaere, A. de Grandcourt, A. Nickless, Y. Nouvellon, R. Scholes, and W. Kutsch. 2013. Improving operational land surface model canopy evapotranspiration in Africa using a direct remote sensing approach. Hydrology and Earth System Science 17: 1079-1091. (T)

Meroni, M., C. Atzberger, C. Vancutsem, N. Gobron, F. Baret, R. Lacaze, H. Eerens, and O. Leo. 2013. Evaluation of agreement between space remote sensing SPOT-VEGETATION fAPAR time series. IEEE Transactions on Geoscience and Remote Sensing 51: 1951-1962. (DE)

Meroni, M., F. Rembold, M.M. Verstraete, R. Gommes, A. Schucknecht, and G. Beye. 2014. Investigating the relationship between the inter-annual variability of satellite-derived vegetation phenology and a proxy of biomass production in the Sahel. Remote Sensing 6: 5868-5884. (PP)

Meroni, M., D. Fasbender, F. Kayitakire, G. Pini, F. Rembold, F. Urbanoa, and M.M. Verstraete. 2014. Early detection of biomass production deficit hot-spots in semi-arid environment using FAPAR time series and a probabilistic approach. Remote Sensing of Environment 142: 57-68. (PP)

Mitchard, E.T.A., S.S. Saatchi, I.H. Woodhouse, G. Nagendo, N.S. Ribeiro, M. Williams, C.M. Ryan, S.L. Lewis, T.R. Feldpausch, and P. Meir. 2009. Using satellite radar backscatter to predict above-ground woody biomass: A consistent relationship across for different African landscapes. Geophysical Research Letters 36: L23401. (TCP)

Monsivais-Huerero, A., I. Chenerie, K. Sarabandi, F. Baup, and E. Mougin. 2010. Microwave electromagnetic modelling of Sahelian grassland. International Journal of Remote Sensing 31: 1915-1972. (PP)

Monsivais-Huertero, A., K. Sarabandi, and I. Chênerie. 2010. Multipolarization microwave scattering model for Sahelian grassland. IEEE Transactions on Geoscience and Remote Sensing 48: 1416-1431. (PP)

Mougin, E., D. Lo Seen, S. Rambal, A. Gaston, and P. Hiernaux. 1995. A regional Sahelian grassland model to be coupled with multispectral satellite data. I: Model description and validation. Remote Sensing of Environment 52: 181-193. (PP) 
Nutini, F., M. Boschetti, G. Candiani, S. Bocchi, and P.A. Brivio. 2014. Evaporative fraction as an indicator of moisture condition and water stress status in semi-arid rangeland ecosystems. Remote Sensing 6: 6300-6323. (T)

Oduolowu, I.A. 1977. Qualitative interpretation of remotely sensored data as a key to mapping vegetation patterns in the western Sudan. GeoJournal 1: 13-20. (VT)

Olsen, J.L., P. Ceccato, S.R. Proud, R. Fensholt, M. Grippa, E. Mougin, J. Ardö, and I. Sandholt. Relation between seasonally detrended shortwave infrared reflectance data and land surface moisture in semi-arid Sahel. Remote Sensing 5: 2898-2927. (WC)

Philippon, N., N. Martiny, and P. Camberlin. 2009. Forecasting the vegetation photosynthetic activity over the Sahel: a model output statistics approach. International Journal of Climatology 29: 1463-1477. (PP)

Qi, J., Y.H. Kerr, M.S. Moran, M. Weltz, A.R. Huete, S. Sorooshian, and R. Bryant. 2000. Leaf Area Index estimates using remotely sensed data and BRDF models in a semiarid region. Remote Sensing of Environment 73: 18-30. (LAI)

Rasmussen, M.S. 1998b. Developing simple, operational, consistent NDVI-vegetation models by applying environmental and climatic information. Part 1: Assessment of net primary production. International Journal of Remote Sensing 19: 97-117. (PP)

Rasmussen, M.O., F.M. Göttesche, D. Diop, C. Mbow, F.S. Olesen, R. Fensholt, and I. Sandholt. 2011. Tree survey and allometric models for tiger bush in northern Senegal and comparison with tree parameters derived from high resolution satellite data. International Journal of Applied Earth Observation and Geoinformation 13: 517-527. (TCP)

Rian, S., Y. Xue, G.M. MacDonald, M.B. Touré, Y. Yu, F. De Sales, P.A. Levine, et al. 2009. Analysis of climate and vegetation characteristics along a savanna-desert ecotone in Mali using MODIS data. GIScience and Remote Sensing 46: 424-450. (VT)

Rigina, O., and M.S. Rasmussen. 2003. Using trend line and principal component analysis to study vegetation changes in Senegal 1986-1999 from AVHRR NDVI 8 km data. Danish Journal of Geography 103: 31-42. (DE)

Ritchie, J.C., M. Menenti, and M.A. Weltz. 1996. Measurements of land surface features using an airborne laser altimeter: the HAPEX-Sahel experiment. International Journal of Remote Sensing 17: 3705-3724. (TCP)

Rosema, A. 1993. Using METEOSAT for operational evapotranspiration and biomass monitoring in the Sahel region. Remote Sensing of Environment 46: 27-44. (PP)

Sandholt I., and H.S. Andersen. 1993. Derivation of actual evapotranspiration in the Senegalese Sahel using NOAA-AVHRR data during the 1987 growing season. Remote Sensing of Environment 46:164-172. (T)

Sandholt, I., K. Rasmussen, and J. Andersen. 2002. A simple interpretation of the surface temperature/vegetation index space for assessment of surface moisture status. Remote Sensing of Environment 79: 213-224. (WC) 
Schmidt, M., S. Traoré, A. Ouédraogo, E. Mbayngone, O. Ouédraogo, A. Zizka, Kirchmair, E. Kaboré, E. Tindano, A. Thiombiano, K. Hahn, and G. Zizka. 2013. Geographical patterns of woody plants' functional traits in Burkina Faso. Candollea 68: 197-207. (VT)

Schmidt, M., K. König, J.V. Müller, U. Brunken, and G. Zizka. 2011. Modelling the distribution of photosynthetic types of grasses in Sahelian Burkina Faso with high-resolution satellite data. Ecotropica 17: 53-63. (VT)

Seaquist, J.W. and Olsson, L. 1999. Rapid estimation of photosynthetically active radiation over the West African Sahel using the Pathfinder Land Data Set. JAG 1 (3/4): 205-213. (PP)

Seaquist, J.W., L. Olsson, and J. Ardö. 2003. A remote sensing-based primary production model for grassland biomes. Ecological Modelling 169: 131-155. (PP)

Sjöström, M., J. Ardö, L. Eklundh, B.A. El-Tahir, H.A. El-Khidir, M. Hellström, P. Pilesjö, and J. Seaquist. 2009. Evaluation of satellite based indices for gross primary production estimates in a sparse savanna in the Sudan. Biogeosciences 6: 129-138. (PP)

Sjöström, M., J. Ardö, A. Arneth, N. Boulin, B. Cappelaere, L. Eklundh, A. de Grandcourt, et al. 2011. Exploring the potential of MODIS EVI for modelling gross primary production across African ecosystems. Remote Sensing of Environment 115: 1081-1089. (PP)

Sjöström, M., M. Zhao, S. Archibald, A. Arneth, B. Cappelaere, U. Falk, A. de Grandcourt, N.P. Hanan, L. Kergoat, W. Kutsch, L. Merbold, E. Mougin, A. Nickless, Y. Nouvellon, R.J. Scholes, E.M. Veenendaal, and J. Ardö. 2013. Evaluation of MODIS gross primary productivity for Africa using eddy covariance data. Remote Sensing of Environment 131: 275-286. (PP)

Stisen, S., I. Sandholt, A. Nørgaard, R. Fensholt, K. Høgh Jensen. 2008. Combining the triangle method with thermal inertia to estimate regional evapotranspiration - Applied to MSG-SEVIRI data in the Senegal River basin. Remote Sensing of Environment 112: 12421255. (T)

Tadesse, T., G. B. Demisse, B. Zaitchik, and T. Dinku. 2014. Satellite-based hybrid drought monitoring tool for prediction of vegetation condition in Eastern Africa: A case study for Ethiopia. Water Resources Research 50: 2176-2190. (PP)

Tappan, G.G., D.G. Moore, and W.I. Knausenberger. 1991. Monitoring grasshopper and locust habitats in Sahelian Africa using GIS and remote sensing technology. International journal of geographical information systems 5: 123-135. (PP)

Tappan, G.G., D.J. Tyler, M.E. Wehde, D.G. Moore. 1992. Monitoring rangeland dynamics in Senegal with Advanced Very High Resolution Radiometer data. Geocarto International 7: 87-98. (PP)

Tchuente, A.T., J.L Roujean, and S.Faroux. 2010. ECOCLIMAP-II: An ecosystem classification and land surface parameters database of Western Africa at $1 \mathrm{~km}$ resolution for the African Monsoon Multidisciplinary Analysis (AMMA) project. Remote Sensing of Environment 114: 961-976. (VT) 
Tucker, C.J., C.L. Vanpraet, E. Boerwinkel, and A. Gaston. 1983. Satellite Remote Sensing of Total Dry Matter Production in the Senegalese Sahel. Remote Sensing of Environment 13: 461-474. (PP)

Tucker, C.J., C.L. Vanpraet, M.J. Sharman, and G. van Ittersum. 1985. Satellite remote sensing of total herbaceous biomass production in the Senegalese Sahel: 1980-1984. Remote Sensing of Environment 17: 233-249. (PP)

Van Leeuwen, W.J.D., A.R Huete, C.L. Walthall, S.D. Prince, A. Bégué, and J.L. Roujean. 1997. Deconvolution of remotely sensed spectral mixtures for retrieval of LAI, fAPAR and soil brightness. Journal of Hydrology 188-189: 697-724. (LAI)

Woodhouse, I.H., and D.H. Hoekman. 2000. Determining Land-Surface Parameters from the ERS Wind Scatterometer. IEEE Transactions on Geoscience and Remote Sensing 38: 126140. (PP)

Wu, W., E. De Pauw, and U. Helldén. 2013. Assessing woody biomass in African tropical savannahs by multiscale remote sensing. International Journal of Remote Sensing 34: 45254549. (TCP)

Wurster, K. 2009. Testing the capability of MISR in detecting forest changes caused by charcoal production in Senegal. International Journal of Remote Sensing 30: 5151-5157. (TCP)

Wylie, B. K., J.A. Harrington, S.D. Prince, and I. Denda. 1991. Satellite and ground based pasture production assessment in Niger: 1986-1988. International Journal of Remote Sensing 6: 1281-1300. (PP)

Wylie, B.K., J.A. Harrington, R.D. Pieper, and I. Dena. 1992. A satellite based range assessment system in the Sahel of Africa. Geocarto International 7: 79-85. (PP)

Wylie, B.K., I. Denda, R.D. Pieper, J.A. Harrington, B.C. Reed, and G.M. Southward. 1995. Satellite-based herbaceous biomass estimates in the pastoral zone of Niger. Journal of Range Management 48: 159-164. (PP)

Zine, S., L. Jarlan, P. Frison, E. Mougain, P. Hiernaux, and J.P. Rudant. 2005. Land surface parameter monitoring with ERS scatterometer data over the Sahel: A comparison between agro-pastoral and pastoral areas. Remote Sensing of Environment 96: 438-542. (PP)

\section{Vegetation and environmental factors}

Key vegetation variable: P (phenology), VP (vegetation production), VT (vegetation type).

$\underline{\text { Key environmental factor: }} \mathbf{R}$ (rainfall), VSO (vegetation self-organization), SP (soil properties), SST (sea surface temperature), $\mathbf{O}$ (other) 
Barbier, N., P. Couteron, J. Lejoly, V. Deblauwe, and O. Lejeune. 2006. Self-organized vegetation patterning as a fingerprint of climate and human impact on semi-arid ecosystems. Journal of Ecology 94: 537-547. (VSO)

Bégué, A., E. Vintrou, A. Saad, and P. Hiernaux. 2014. Differences between cropland and rangeland MODIS phenology (start-of-season) in Mali. International Journal of Applied Earth Observation and Geoinformation 31: 167-170. (P-O)

Bobée, C., C. Ottlé, F. Maignan, N. de Noblet-Ducoudré, P. Maugis, A-M. Lézine, and M. Ndiaye. Analysis of vegetation seasonality in Sahelian environments using MODIS LAI, in association with land cover and rainfall. Journal of Arid Environments 84: 38-50. (P-SP)

Brown, M.E., K. de Beurs, and A. Vrieling. 2010. The response of African land surface phenology to large scale climate oscillations Remote Sensing of Environment 114: 22862296. (P-SST)

Couteron, P. 2001. Using spectral analysis to confront distributions of individual species with an overall periodic pattern in semi-arid vegetation. Plant Ecology 156:1-15. (VSO)

Couteron, P., and O. Lejeune. 2001. Periodic spotted pattern in semi-arid vegetation explained by a propagation-inhibition model. Journal of Ecology 89: 616-628. (VSO)

Couteron, P. 2002. Quantifying change in patterned semi-arid vegetation by Fourier analysis of digitized aerial photographs. International Journal of Remote Sensing 23: 3407-3425.

(VSO)

Dardel, C., L. Kergoat, P. Hiernaux, M. Grippa, E. Mougin, P. Ciais, and C.C. Nguyen. 2014. Rain-use-efficiency: what it tells us about the conflicting Sahel greening and Sahelian paradox. Remote Sensing 6: 3446-3474. (VP-SP)

Deblauwe, V., P. Couteron, O. Lejeune, J. Bogaert, and N. Barbier. 2011. Environmental modulation of self-organized periodic vegetation patterns in Sudan. Ecography 34: 990-1001. (VSO)

d'Herbés, J.M., and C. Valentin. 1997. Surface conditions of the Niamey region: ecological and hydrological implications. Journal of Hydrology 188-189: 1842. (VT-SP)

Dieye, A.M., D. P. Roy, N. P. Hanan, S. Liu, M. Hansen, and A. Touré. 2012. Sensitivity analysis of the GEMS soil organic carbon model to land cover land use classification uncertainties under different climate scenarios in Senegal. Biogeosciences 9: 631-648. (VTSP)

Grégoire, J.M. 1990. Effects of the dry season on the vegetation canopy of some river basins of West Africa as deduced from NOAA-AVHRR. Hydrological sciences 35: 323-338. (VPR)

Hielkema, J.U., S.D. Prince, and W.L. Astle. 1986. Rainfall and vegetation monitoring in the savanna zone of the Democratic Republic of Sudan using the NOAA Advanced Very High Resolution Radiometer. International Journal of Remote Sensing 7: 1499-1513 (VP-R) 
Hiernaux, P., and B. Gérard. 1999. The influence of vegetation pattern on the productivity, diversity and stability of vegetation: The case of "brousse tigrée" in the Sahel. Acta Oecologica 20: 147-158. (VSO)

Huber, S. and R. Fensholt. 2011. Analysis of teleconnections between AVHRR-based sea surface temperature and vegetation productivity in the semi-arid Sahel. Remote Sensing of Environment 115: 3276-3285. (VP-SST)

Huber, S., R. Fensholt, and K. Rasmussen. 2011. Water availability as the driver of vegetation dynamics in the African Sahel from 1982 to 2007. Global and Planetary Change 76: 186-195. (VP-R)

Jarlan, L., Tourre, Y.M., Mougin, E., Philippon, N. and Mazzega, P. 2005. Dominant patterns of AVHRR NDVI interannual variability over the Sahel and linkages with key climate signals (1982-2003). Geophysical Research Letters, vol. 32, no. 4, Article ID L04701, 4 pages, 2005. (VP-SST)

Johnson, K., M.E. Brown. 2014. Environmental risk factors and child nutritional status and survival in a context of climate variability and change.Applied Geography 54: 209-221. (VPO)

Justice, C.O., G. Dugdale, J.R. Townshend, A.S. Narracott, and M. Kumar. 1991. Synergism between NOAA-AVHRR and Meteosat data for studying vegetation development in semiarid West Africa. International Journal of Remote Sensing 12: 1349-1368. (VP-R)

Kumar, L., M. Rietkerk, F van Langevelde, J. van de Koppel, J. van Andel, J. Hearne, N. de Ridder, et al. 2002. Relationship between vegetation growth rates at the onset of the wet season and soil type in the Sahel of Burkina Faso: implications for resource utilization at large scales. Ecological Modeling 149: 143-152. (VP-SP)

Lind, M., and R. Fensholt. 1999. The spatio-temporal relationship between rainfall and vegetation development in Burkina Faso. Danish Journal of Geography 2: 43-55. (VP-R)

Malo, A.R., and S.E. Nicholson. 1990. A study of rainfall and vegetation dynamics in the African Sahel using Normalized Difference Vegetation Index. Journal of Arid Environments 19: 1-24. (VP-R)

Martiny, N., P. Camberlin, Y. Richard, and N. Philippon. 2006. Compared regimes of NDVI and rainfall in semi-arid regions of Africa. International Journal of Remote Sensing 27:52015223. (VP-R)

Nicholson, S.E., M.L. Davenport, and A.R. Malo. 1990. A comparison of the vegetation response to rainfall in the Sahel and East Africa, using Normalized Difference Vegetation Index from NOAA AVHRR. Climatic Change 17: 209-241. (VP-R)

Ockendon, N., A. Johnston, and S.R. Baillie. 2014. Rainfall on wintering grounds affects population change in many species of Afro-Palaearctic migrants. Journal of Ornithology 155: 905-917. (VP-O) 
Philippon, N., E. Mougin, L. Jarlan, and P. Frison. 2005. Analysis of the linkages between rainfall and land surface conditions in the West African monsoon through CMAP, ERSWSC, and NOAA-AVHRR data. Journal of Geophysical Research 110: D24115. (VP-R)

Philippon, N., L. Jarlan, N. Martiny, P. Camberlin, and E. Mougin. 2007. Characterization of the interannual and intra seasonal variability of West African vegetation between 1982 and 2002 by means of NOAA AVHRR NDVI data. Journal of Climate 20: 1202-1218. (P-R)

Pierre, C., G. Bergametti, B. Marticorena,E. Mougin, T. Lebel, and A. Ali. 2011. Pluriannual comparisons of satellite-based rainfall products over the Sahelian belt for seasonal vegetation modeling. Journal of Geophysical Research 116: D18201. (VP-R)

Proud, S.R., and L. Vang Rasmussen. 2011. The influence of seasonal rainfall upon Sahel vegetation. Remote Sensing Letters 2: 241-249. (VP-R)

Rian, S., Y. Xue, G.M. MacDonald, M.B. Touré, Y. Yu, F. De Sales, P.A. Levine, et al. 2009. Analysis of climate and vegetation characteristics along a savanna-desert ecotone in Mali using MODIS data. GIScience and Remote Sensing 46: 424-450. (VT-R)

Soti, V., V. Chevalier, J, Maura1, A. Bégué, C. Lelong, R. Lancelot, Y. Thiongane, and A. Tran. 2013. Identifying landscape features associated with Rift Valley fever virus transmission, Ferlo region, Senegal, using very high spatial resolution satellite imagery. International Journal of Health Geographics 12:10. (VP-O)

Tagesson, T., R. Fensholt, I. Guiro, M.O. Rasmussen, S. Huber, C. Mbow, M. Garcia, S. Horion, I. Sandholt, B. Holm-Rasmussen, F. Göttsche, M.E., Ridler, N. Olén, J. Lundegard, A Ehammer, M. Madsen, F.S. Olesen, and J. Ardö. 2014. Ecosystem properties of semiarid savanna grassland in West Africa and its relationship with environmental variability. Global Change Biology 21, doi: 10.1111/gcb.12734 250-264. (VP-R)

\section{Vegetation change}

Key: $\mathbf{P}$ (phenology), TCP (tree cover properties), VP (vegetation production), VT (vegetation type)

Abdi, A.M., J. Seaquist, D.E. Tenenbaum, L. Eklundh, and J. Ardö. 2014. The supply and demand of net primary production in the Sahel. Environmental Research Letters 9: 094003. (VP)

Ahmedou, O.C., R. Nagasawa, A.E. Osman, and K. Hattori. 2008. Rainfall variability and vegetation dynamics in the Mauritanian Sahel. Climate Research 38: 75-81. (VT)

Alemayehu, F., N. Taha, J. Nyssen, A. Girma, A. Zenebe, M. Behailu, S. Deckers, and J.

Poesen. 2009. The impacts of watershed management on land use and land cover dynamics in Eastern Tigray (Ethiopia). Resources, Conservation and Recycling 53: 192-198. (VT)

Amissah-Arthur, A., B. Mougenot, M. Loireau. 2000. Assessing farmland dynamics and land degradation in Sahelian landscapes using remote sensed and socioeconomic data.

International Journal of Geographic Information Science 14: 583-599. (VT) 
Amsalu, A., L. Stroosnijder, and J. de Graaff. 2007. Long-term dynamics in land resource use and the driving forces in the Beressa watershed, highlands of Ethiopia. Journal of Environmental Management 83: 448-459. (VT)

Anyamba, A., and C.J. Tucker. 2005. Analysis of Sahelian vegetation dynamics using NOAA-AVHRR NDVI data from 1981-2003. Journal of Arid Environments 63: 596-614. (VP)

Ayanu, Y., A. Jentsch,D. Muller-Mahn, S. Rettberg, C. Romankiewicz, T. Koellner. Ecosystem engineer unleashed: Prosopis juliflora threatening ecosystem services? Regional Environmental Change 15: 155-167. (VT)

Babamaaji, R.A., and J. Lee. 2014. Land use/land cover classification of the vicinity of Lake Chad using NigeriaSat-1 and Landsat data. Environmental Earth Sciences 71: 4309-4317. (VT)

Bégué, A., E. Vintrou, D. Ruelland, M. Claden, and N. Dessay. 2011. Can a 25-year trend in Soudano-Sahelian vegetation dynamics be interpreted in terms of land use change? A remote sensing approach. Global Environmental Change 21: 413-420. (VP)

Belay, T.A., Ø. Totland, and S.R. Moe. 2013. Woody vegetation dynamics in the rangelands of lower Omo region, southwestern Ethiopia. Journal of Arid Environments 89: 94-102. (VT)

Belay, K. T., A. Van Rompaey, J. Poesen, S. Van Bruyssel, J. Deckers, and K. Amare. 2014. Spatial analysis of land cover changes in eastern Tigray (Ethiopia) from 1965 to 2007: are there signs of a forest transition? Land Degradation and Development: doi: 10.1002/ldr.2275 (VT)

Benjaminsen, T.A. 2001. The population-agriculture-environment nexus in the Malian cotton zone. Global Environmental Change 11: 283-295. (VT)

Biazina, B., and G. Sterk. 2013. Drought vulnerability drives land-use and land cover changes in the Rift Valley dry lands of Ethiopia. Agriculture, Ecosystems and Environment 164: 100- 113. (VT)

Biro, K., B. Pradhan, M. Buchroithner, and F. Makeschin. 2013. Land use/land cover change analysis and its impact on soil properties in the northern part of Gadarif region, Sudan. Land degradation and Development 24: 90-102. (VT)

Black, R. and M.F Seesay. 1997. Refugees, land cover and environmental change in the Senegal River Valley. GeoJournal 41: 55-67. (VT)

Boschetti, M., F. Nutini, P.A. Brivio, E. Bartholomé, D. Stroppiana, and A. Hoscilo. 2013. Identification of environmental anomaly hot spots in West Africa from time series of NDVI and rainfall. ISPRS Journal of Photogrammetry and Remote Sensing 78: 26-40. (VP)

Brandt, M., A. Verger, A.A. Diouf, F. Baret, and C. Samimi. 2014a. Local vegetation trends in the Sahel of Mali and Senegal using long time series FAPAR satellite products and field measurement (1982-2010). Remote Sensing 6: 2408-2434. (VP) 
Brandt, M., C. Romankiewicz, R. Spiekermann, C. Samimi. 2014b. Environmental change in time series: An interdisciplinary study in the Sahel of Mali and Senegal. Journal of Arid Environments 105: 52-63. (VP)

Brink, A.B., and H.D. Eva. 2011. The potential use of high-resolution Landsat satellite data for detecting land-cover change in the Greater Horn of Africa. International Journal of Remote Sensing 32: 5981-5995. (VT)

Brinkmann, K., J. Schumacher, A. Dittrich, I. Kadaore, and A. Buerkerta. 2012. Analysis of landscape transformation processes in and around four West African cities over the last 50 years. Landscape and Urban Planning 105: 94-105. (VT)

Brottem, L., M.D. Turner, B. Butt, and A. Singh. 2014. Biophysical variability and pastoral rights to resources: West African transhumance revisited. Human Ecology 42: 351-365. (P)

Budde, M.E., G.G Tappan, J. Rowland, J. Lewis, and L.L. Tieszen. 2004. Assessing land cover performance in Senegal, West Africa using 1-km integrated NDVI and local variance analysis. Journal of Arid Environments 59: 481-498. (VP)

Butt, B., M.D. Turner, A. Singh, L.Brottem. 2011. Use of MODIS NDVI to evaluate changing latitudinal gradients of rangeland phenology in Sudano-Sahelian West Africa. Remote Sensing of Environment 115: 3367-3376. (P)

Capecchi, V., A. Crisci, G. Lorenzo, F. Maselli, and P. Vignaroli. 2008. Analysis of NDVI trends and their climatic origin in the Sahel 1986-2000. Geocarto International 23: 297-310. (C-VP)

Carney, J., T.W. Gillespie, and R. Rosomoff. 2014. Assessing forest change in a priority West African mangrove ecosystem: 1986-2010. Geoforum 53: 126-135. (VT)

Conchedda, G., L. Durieux, and P. Mayaux. 2008. An object-based method for mapping and change analysis in mangrove ecosystems. ISPRS Journal of Photogrammetry and Remote Sensing 63: 578-89. (VT)

Conchedda, G., E.F. Lambin, P. Mayaux. 2011. Between land and sea: livelihoods and environmental changes in mangrove ecosystems of Senegal. Annals of the Association of American Geographers 101: 1259-1284. (VT)

Dardel, C., L. Kergoat, P. Hiernaux, M. Grippa, E. Mougin, P. Ciais, and C.C. Nguyen. 2014. Rain-use-efficiency: what it tells us about the conflicting Sahel greening and Sahelian paradox. Remote Sensing 6: 3446-3474. (VP)

Dardel, C., L. Kergoat, P. Hiernaux, E. Mougin, M. Grippa, and C.J. Tucker. 2014. Regreening Sahel: 30 years of remote sensing data and field observations (Mali, Niger). Remote Sensing of Environment 140: 350-364. (VP)

Dawelbait, M., and F. Morari. 2011. Landsat, spectral mixture analysis and change vector analysis to monitor land cover degradation in a savanna region in Sudan. International Journal of Water Resources and Arid Environments 1: 366-377. (VT) 
Dawelbait, M., and F. Morari. 2012. Monitoring desertification in a Savannah region in Sudan using Landsat images and spectral mixture analysis. Journal of Arid Environments 80: 45-55. (VT)

De Muelenaere, S., A. Frankl, M. Haile, J. Poesen, J. Deckers, N. Munro, S. Veraverbeke, and J. Nyssen. 2014. Historical landscape photographs for calibration of Landsat land use/cover in the northern Ethiopian highlands. Land Degradation and Development 25: 319335. (VT)

Diouf, A., and E.F. Lambin. 2001. Monitoring land-cover changes in semi-arid regions: remote sensing data and field observations in the Ferlo, Senegal. Journal of Arid Environments 48: 129-148. (VP)

Eklundh, L. and L. Olsson. 2003. Vegetation index trends for the African Sahel 1982-1999. Geophysical Research Letters 30 (8) 1430. (VP)

Elhag, M., and S. Walker. 2009. Impact of climate variability on vegetative cover in the Butana area of Sudan. African Journal of Ecology, 47: 11-16. (VP)

Fensholt, R., K. Rasmussen, P. Kaspersen, S. Huber, S. Horion, and E. Swinnen. 2013. Assessing Land Degradation/Recovery in the African Sahel from Long-Term Earth Observation Based Primary Productivity and Precipitation Relationships. Remote Sensing 5: 644-686. (VP)

Fensholt, R., and K. Rasmussen. 2011. Analysis of trends in the Sahelian 'rain-use efficiency' using GIMMS NDVI, RFE and GPCP rainfall data. Remote Sensing of Environment 115: 438-451. (VP)

Foody, G.M. 2001. Monitoring the magnitude of land-cover change around the southern limits of the Sahara. Photogrammetric Engineering and Remote Sensing 67: 841-847. (VP)

Freemantle, T.P.,T.Wacher, J. Newby, and N. Pettorelli. 2013. Earth observation: overlooked potential to support species reintroduction programs. African Journal of Ecology 51: 482492. (VP)

Fuller, D.O. 1998. Trends in NDVI time series and their relation to rangeland and crop production in Senegal, 1987-1993. International Journal of Remote Sensing 19: 2013-2018. (VP)

Gebrelibanos, T., and M. Assen. 2013. Land use/land cover dynamics and their driving forces in the Hirmi watershed and its adjacent agro-ecosystem, highlands of northern Ethiopia. Journal of Land Use Science 10: 81-94. (VT)

Gebresamuel, G., B.R. Singh, Ö. Dick. 2010. Land-use changes and their impacts on soil degradation and surface runoff of two catchments of Northern Ethiopia. Acta Agriculturae Scandinavica Section B - Soil and Plant Science 60: 211-226. (VT)

Gelet, M., K.V. Suryabhagavan, and M. Balakrishnan. 2010. Land-use and landscape pattern changes in Holeta-Berga watershed, Ethiopia. International Journal of Ecology and Environmental Sciences 36: 117-132. (VT) 
Goita, K., and A. Royer. 1992. Land surface climatology and land cover change monitoring since 1973 over a North-Sahelian Zone (Ansongo-Mali) using Landsat data. Geocarto International 2: 15-28. (VT)

Gonzalez, P. 2001. Desertification and a shift of forest species in the West African Sahel. Climate research 17: 217-228. (TCP)

Gonzalez, P., C.J. Tucker, and H. Sy. 2012. Tree density and species decline in the African Sahel attributable to climate. Journal of Arid Environments 78: 55-64. (TCP)

Gray, L.C. 1999. Is land being degraded? A multi-scale investigation of landscape change in southwestern Burkina Faso. Land Degradation and Development 10: 329-343. (VT)

Grolle, J. 2013. High-resolution mapping of rural poverty and famine vulnerability in the Sahel: a possible approach for the Republic of Niger. Population and Environment 35: 68-97. (VT)

Hagenlocher, M., S. Lang, and D. Tiede. 2012. Integrated assessment of the environmental impact of an IDP camp in Sudan based on very high resolution multi-temporal satellite imagery. Remote Sensing of Environment 126: 27-38. (VT)

Hanan, N.P., Y. Prevost, A. Diouf, and O. Diallo. 1991. Assessment of desertification around deep wells in the Sahel. Journal of Applied Ecology 28: 173-186. (VP)

Harrington, J.A., B.K. Wylie, and C.J. Tucker. 1988. Integrated NDVI images for Niger, 1986-1987. Geocarto International 3: 37-40. (VP)

Herrmann, S.M., A. Anyamba, and C.J. Tucker. 2005. Recent trends in vegetation dynamics in the African Sahel and their relationship to climate. Global Environmental Change 15: 394404. (VP)

Herrmann, S.M., and G.G. Tappan. 2013. Vegetation impoverishment despite greening: A case study from central Senegal. Journal of Arid Environments 90: 55-66. (VP)

Herrmann, S. M., I. Sall, and O. Sy. 2014. People and pixels in the Sahel: a study linking coarse-resolution remote sensing observations to land users' perceptions of their changing environment in Senegal. Ecology and Society 19: 29. (VP)

Herrmann, S.M., A.J. Wickhorst, and S.E. Marsh. 2013. Estimation of Tree Cover in an Agricultural Parkland of Senegal Using Rule-Based Regression Tree Modeling. Remote Sensing 5: 4900-4918. (TCP)

Heumann, B.W., J.W. Seaquist, L. Eklundh, and P. Jönsson. 2007. AVHRR derived phenological change in the Sahel and Soudan, Africa, 1982-2005. Remote Sensing of Environment 108: 385-392. (P)

Hickler, T., L. Eklundh, J.W. Seaquist, B. Smith, J. Ardö, L. Olsson, M.T. Sykes, and M. Sjöström. 2005. Precipitation controls Sahel greening trend. Geophysical Research Letters 32: 214-215. L21415. (VP) 
Hiernaux, P., A. Ayantunde, A. Kalilou, E. Mougin, B. Gérard, F. Baup, M. Grippa, and B. Djaby. 2009. Trends in productivity of crops, fallow and rangelands in Southwest Niger: Impact of land use, management and variable rainfall Journal of Hydrology 375: 65-77. (VP)

Horion, S., R. Fensholt, T. Tagesson, and A. Ehammer. 2014. Using earth observation-based dry season NDVI trends for assessment of changes in tree cover in the Sahel. International Journal of Remote Sensing 35: 2493-2515. (TCP)

Hountondji, Y.C., N. Sokpon, and P. Ozer. 2006. Analysis of the vegetation trends using low resolution remote sensing data in Burkina Faso (1982-1999) for the monitoring of desertification. International Journal of Remote Sensing 27: 871-884. (VP)

Howorth, C. and O’Keefe, P. 1999. Farmers do it better: Local management of change in southern Burkina Faso. Land Degradation and Development 10: 93-109. (VT)

Huber, S., R. Fensholt, and K. Rasmussen. 2011. Water availability as the driver of vegetation dynamics in the African Sahel from 1982 to 2007. Global and Planetary Change 76: 186-195. (VP)

Jamali, S., J. Seaquist, L. Eklundh, and J. Ardö. 2014. Automated mapping of vegetation trends with polynomials using NDVI imagery over the Sahel. Remote Sensing of Environment 141: 79-89. (VP)

Junge, B., T. Alabi, S. Marcus, R. Abaidoo, D. Chikoye, and K. Stahr. 2010. Use of remote sensing and GIS for improved natural resources management: case study from different agroecological zones of West Africa. International Journal of Remote Sensing 31: 61156141. (VT)

Kelder, Y., T.T. Nielsen, and R. Fensholt. 2013. The Role of Methodology and Spatiotemporal Scale in Understanding Environmental Change in Peri-Urban Ouagadougou, Burkina Faso. Remote Sensing 5: 1465-1483. (VP + VT)

Kogan, F.N. 1990. Remote sensing of weather impacts on vegetation in non-homogeneous area. International Journal of Remote Sensing 11: 1405-1419. (VP)

Lambin, E.F., and A.H. Strahler. 1994. Change-vector analysis in multitemporal space: a tool to detect and categorize land-cover change processes using high temporal-resolution satellite data. Remote Sensing of Environment 48: 231-244. (VP)

Lambin, E.F. 1996. Change detection at multiple temporal scales: seasonal and annual variations in landscape variables. Photogrammetric Engineering and Remote Sensing 62: 931-938. (VP)

Larsson, H. 2002. Analysis of variations in land cover between 1972 and 1990, Kassala Province, Eastern Sudan, using Landsat MSS data. International Journal of Remote Sensing 23: 325-333. (TCP)

Leblanc, M.J., G. Favreau, S. Massuel, S.O. Tweed, M. Loireau, and B. Cappelaere. 2008. Land clearance and hydrological change in the Sahel: Sw Niger. Global and Planetary Change 61: 135-150. (TCP) 
Li, J., J. Lewis, J. Rowland, G.G Tappan, and L.L. Tieszen. 2004. Evaluation of land performance in Senegal using multi-temporal NDVI and rainfall series. Journal of Arid Environments 59: 463-480. (VP)

Lind, M., K. Rasmussen, H. Adriansen, and A. Ka. 2003. Estimating vegetative productivity gradients around watering points in the rangelands of Northern Senegal based on NOAA AVHRR data. Danish Journal of Geography 103: 1-15. (VP)

Lindqvist, S., and A. Tengberg. 1993. New evidence of desertification from case studies in northern Burkina Faso. Geografiska Annaler. Series A. Physical Geography 75:127-135. (VT)

Lykke, A.M., B. Fog, and J.E. Madsen. 1999. Woody vegetation changes in the Sahel of Burkina Faso assessed by means of local knowledge, aerial photos and botanical investigation. Danish Journal of Geography 2: 57-68. (TCP)

Madsen, J.E., M. Lind, and B. Fog. 1999. Accuracy of aerial photos for recognizing trees in West African cultural landscapes. Danish Journal of Geography 2: 139-148. (TCP)

Martinez, B., M.A. Gilabert, F.J. Garcia-Haro, A. Faye, and J. Melia. 2011. Characterizing land condition variability in Ferlo, Senegal (2001-2009) using multi-temporal 1-km Apparent Green Cover (AGC) SPOT Vegetation data. Global and Planetary Change 76: 152-165. (VP)

Maselli, F., C. Conese, L. Petkov, and M. Gilabert. 1992. Use of NOAA-AVHRR NDVI data for environmental monitoring and crop forecasting in the Sahel. Preliminary results. International Journal of Remote Sensing 13: 2743-2749. (VP)

Matheson,W., and S. Ringrose. 1994. Assessment of degradation features and their development into the post-drought period in the west central Sahel using Landsat MSS. Journal of Arid Environments 26: 181-199. (VT)

Mbow, C., O. Mertz, A. Diouf, K. Rasmussen, and A. Reenberg. 2008. The history of environmental change and adaptation in eastern Saloum Senegal - Driving forces and perceptions. Global and Planetary Change 64: 210-221. (VT)

Mbow, C., R. Fensholt, K. Rasmussen, and D. Diop. 2013. Can vegetation productivity be derived from greenness in a semi-arid environment? Evidence from ground-based measurements. Journal of Arid Environments 97: 56-65. (VP)

Meshesha, D.T., A. Tsunekawa, and M. Tsubo. 2012. Continuing land degradation: causeeffect in Ethiopias Central Rift Valley. Land Degradation and Development 23: 130-143. (VT)

Milich, L., \& E. Weiss (1997) Characterization of the Sahel: Implications of correctly calculating interannual coefficients of variation (CoVs) from GAC NDVI values, International Journal of Remote Sensing, 18: 3749-3759. (VP) 
Milich, L., and E. Weiss. 2000a. GAC NDVI interannual coefficient of variation (CoV) images: ground thruth sampling of the Sahel along north-south transects. International Journal of Remote Sensing 21: 235-260. (VP)

Milich, L., and E. Weiss. 2000b. GAC NDVI images: Relationship to rainfall and potential evapotranspiration in the grazing lands of the Gourma (northern Sahel) and in the croplands of Niger-Nigeria boarder (southern Sahel). International Journal of Remote Sensing 21: 261280. (VP)

Mitchard, E.T.A. and C.M. Flintrop. 2013. Woody encroachment and forest degradation in sub-Saharan Africa's woodlands and savannas 1982-2006. Philosophical Transactions of the Royal Society 368: 20120406. (TCP)

Mohammed, S.O., A. Farsad, and J. Farifteh. 1996. Evaluating land degradation for assessment of land vulnerability to desert conditions in the Sokoto area, Nigeria. Land Degradation and Development 7: 205-215. (VT)

Mohler, R.R.J., and D.L. Amsbury. 1988. Extension of a drought monitoring and vegetation classification methodology to the western Sahel. Geocarto International 3: 28-36. (VP)

Mortimore, M., F.M. Harris, and B. Turner. 1999. Implications of land use change for the production of plant biomass in densely populated Sahelo-Sudanian shrub grasslands in northeast Nigeria. Global Ecology and Biogeography 8: 243-256. (VT)

Niang, A.J., A. Ozer, and P. Ozer. 2008. Fifty years of landscape evolution in southwestern Mauritania by means of aerial photos. Journal of Arid Environments 72: 97-107. (VT)

Nicholson, S.E., C.J. Tucker, and M.B. Ba. 1998. Desertification, drought and surface vegetation: An example from the West African Sahel. Bulletin of the American Meterological Society 79: 815-829. (VP)

Nutini, F., M. Boschetti, P.A. Brivio, S. Bocchi, and M. Antoninetti. 2013. Land-use and land-cover change detection in a semi-arid area of Niger using multi-temporal analysis of Landsat images, International Journal of Remote Sensing 34: 4769-4790. (VT)

Nyssen, J., G. Simehn, and N. Taha. 2009. An upland farming system under transformation: Proximate causes of land use change in Bela-Welleh catchment (Wag, Northern Ethiopian highlands). Soil and Tillage Research 103: 231-238. (VT)

Oduori, S.M., F. Rembold, O.H. Abdulle, and R. Vargas. 2011. Assessment of charcoal driver deforestation rates in a fragile rangeland environment in North Eastern Somalia using very high resolution imagery. Journal of Arid Environments 75: 1173-1181. (TCP)

Okonkwo, C., B. Demoz, and K. Onyeukwu. 2013. Characteristics of drought indices and rainfall in Lake Chad Basin. International Journal of Remote Sensing, 34: 7945-7961. (VP)

Olsson, L., L. Eklundh, and J. Ardö. 2005. A recent greening of the Sahel - trends, patterns and potential causes. Journal of Arid Environments 63: 556-566. (VP) 
Omuto, C.T., Z. Balint, and M.S. Alim. 2014. A framework for national assessment of land degradation in the drylands: a case study of Somalia. Land Degradation and Development 25: 105-119. (VP)

Ouedraogo, I., P. Savadogo, M. Tigabu, R. Cole, P.C. Odén, and J.M. Ouadba. 2009. Is rural migration a threat to environmental sustainability in southern Burkina Faso? Land degradation and Development 20: 217-230. (VT)

Ouedraogo, I., M. Tigabu, P. Savadogo, H. Compaoré, P.C. Odén, and J.M. Ouadba. 2010. Land cover change and its relation with population dynamics in Burkina Faso, West Africa. Land degradation and Development 21: 453-462. (VT)

Ouedraogo, I., P. Savadogo, M. Tigabu, R.Cole, P.C. Odén, and J.M. Oudba. 2011a. Trajectory analysis of forest cover change in the tropical dry forest of Burkina Faso, West Africa. Landscape Research 36: 303-320. (VT)

Ouedraogo, I., P. Savadogo, M. Tigabu, S.D. Dayamba, and P.C. Odén. 2011b. Systematic and random transitions of land cover types in Burkina Faso. International Journal of Remote Sensing 32: 5229-5245. (VT)

Paré, S., U. Söderberg, M. Sandewall, and J.M. Ouadba. 2008. Land use analysis from spatial and field data capture in southern Burkina Faso, West Africa. Agriculture, Ecosystems and Environment 127: 277-285. (VT)

Pilon, P.G., P.J. Howarth, and R.A. Bullock. 1988. An enhanced classification approach to change detection in semi-arid environments. Photogrammetric Engineering and Remote Sensing 54: 1709-1716. (VT)

Prince, S.D., E. Brown De Colsoun, and L.L. Kravitz. 1998. Evidence from rain-use efficiency does not indicate extensive Sahelian desertification. Global Change Biology 4: 359-374. (VP)

Rasmussen, K., B. Fog, and J.E. Madsen. 2001. Desertification in reverse? Observations from northern Burkina Faso. Global Environmental Change 11: 271-282. (VT)

Rasmussen, K., R. Fensholt, B. Fog, L. Vang Rasmussen, and I. Yanogo. 2014. Explaining NDVI trends in northern Burkina Faso. Danish Journal of Geography 114: 17-24. (VT + VP)

Reenberg, A., C. Mbow, B. Diallo, M. Ba, A. Touré, and A. Noergaard. 2009.

Conceptualizing the change process in Sudano-Sahelian landscapes: Land use and land cover dynamics in forest reserves and their margins. West African Journal of Applied Ecology 15: 105-125. (VT)

Reij, C., G.G. Tappan, and A. Belemvire. 2005. Changing land management practices and vegetation on the Central Plateau of Burkina Faso (1968-2002). Journal of Arid Environments 63: 642-659. (VT)

Rembold, F., S. Carnicelli, M. Nori, and G. Ferrari. 2000. Use of aerial photographs, Landsat TM imagery and multidisciplinary field survey for land-cover change analysis in the lakes 
region (Ethiopia). International Journal of Applied Earth Observation and Geoinformation 2: 181-189. (VT)

Rembold, F., S.M. Oduori, H. Gadain, P. Toselli. 2013. Mapping charcoal driven forest degradation during the main period of Al Shabaab control in Southern Somalia. Energy for Sustainable Development 17: 510-514. (TCP)

Rigina, O., and M.S. Rasmussen. 2003. Comparing time series of AVHRR LAC data with the IGBP $1 \mathrm{~km}$ and the Pathfinder 8 km datasets. Danish Journal of Geography 103:17-29. (VP)

Ringrose, S. and W. Matheson. 1992. The use of Landsat MSS imagery to determine the aerial extent of woody vegetation cover change in the west-central Sahel. Global Ecology and Biogeography Letters 2: 16-25. (TCP)

Ruelland, D., A. Dezetter, C. Puech, and S. Ardoin-Bardin. 2008. Long-term monitoring of land cover changes based on Landsat imagery to improve hydrological modeling in West Africa. International Journal of Remote Sensing 29: 3533-3551. (VT)

Ruelland, D., F. Levavasseur, and A. Tribotté. 2010. Patterns and dynamics of land-cover changes since the 1960s over three experimental areas in Mali. International Journal of Applied Earth Observation and Geoinformation 125: S11-S17. (VT)

Ruelland, D., A. Tribotte, C. Puech, and C. Dieulin. 2011. Comparison of methods for LUCC monitoring over 50 years from aerial photographs and satellite images in a Sahelian catchment. International Journal of Remote Sensing 32: 1747-1777. (VT)

Salim, H.A., X. Chen, and J. Gong. 2008. Analysis of Sudan vegetation dynamics using NOAA-AVHRR NDVI data from 1982-1993. Asian Journal of Earth Sciences 1: 1-15. (VP)

Schleisinger, W.H., and N. Gramenopoulos. 1996. Archival photographs show no climate induced changes in woody vegetation in the Sudan, 1943-1994. Global Change Biology 2: 137-141. (TCP)

Seaquist, J.W., L. Olsson, J. Ardö, and L. Eklundh. 2006. Broad-scale increase in NPP quantified for the African Sahel, 1982-1999. International Journal of Remote Sensing 27: 5115-5122. (VP)

Seaquist, J.W., T. Hickler, L. Eklundh, J. Ardö, and B.W. Heumann. 2009. Disentangling the effects of climate and people on Sahel vegetation dynamics. Biogeoscience 6: 469-477. (VP)

Skougaard Kaspersen, P., R. Fensholt, and S. Huber. 2011. Spatiotemporal Analysis of Climatic Drivers for Observed Changes in Sahelian Vegetation Productivity (1982-2007). International Journal of Geophysics Volume 2011, Article ID 715321. (VP)

Sulieman, H.M. 2010. Expansion of mechanized rain-fed agriculture and land-use/land-cover change in southern Garadif, Sudan. African Journal of Agricultural Research 5: 1609-1615. (VT)

Sulieman, H.M. and N.A. Elagib. 2012. Implications of climate, land-use and land-cover changes for pastoralism in eastern Sudan. Journal of Arid Environments 85: 132-141. (VT) 
Tagesson, T., R. Fensholt, I. Guiro, M.O. Rasmussen, S. Huber, C. Mbow, M. Garcia, S. Horion, I. Sandholt, B. Holm-Rasmussen, F. Göttsche, M.E., Ridler, N. Olén, J. Lundegard, A Ehammer, M. Madsen, F.S. Olesen, and J. Ardö. 2014. Ecosystem properties of semiarid savanna grassland in West Africa and its relationship with environmental variability. Global Change Biology 21, doi: 10.1111/gcb.12734 250-264. (VP)

Tappan, G.G., A. Hadj, E.C. Wood, and R.W. Lietzow. 2000. Use of Argon, Corona and Landsat imagery to assess 30 years of land resource changes in west-central Senegal. Photogrammetric Engineering and Remote Sensing 66: 727-735. (VT)

Tappan, G.G., M. Sall, E.C. Wood, and M. Cushing. 2004. Ecoregions and land cover trends in Senegal. Journal of Arid Environments 59: 427-462. (VT)

Tappan, G.G., and M. McGahuey. 2007. Tracking environmental dynamics and agricultural intensification in southern Mali. Agricultural Systems 94: 38-51. (VT)

Temesgen, H., J. Nyssen, A. Zenebe, N. Haregeweyn, M. Kindu, M. Lemenih, and M. Haile. 2013. Ecological succession and land use changes in a lake retreat area (Main Ethiopian Rift Valley). Journal of Arid Environments 91: 53-60. (VT)

Thiam, A.K. 2003. The causes and spatial pattern of land degradation risk in southern Mauritania using multitemporal AVHRR-NDVI imagery and field data. Land Degradation and Development 14: 133-142. (VP)

Tottrup, C., and M.S. Rasmussen. 2004. Mapping long-term changes in savannah crop productivity in Senegal through trend analysis of time series of remote sensing data. Agriculture, Ecosystems and Environment 103: 545-560. (VP)

Trigg, S., J. Dempewolf, M. Elgamri, C. Justice, and V. Gorsevski. 2012. Fire and land use change heighten tensions between pastoral nomads and mechanized farmers in Kordofan and White Nile States, Sudan. Journal of Land Use Science 7: 275-288. (VP + VT)

Tsegaye, D., S.R. Moe, P. Vedeld, and E. Aynekulu. 2010. Land-use/cover dynamics in northern Afar rangelands, Ethiopia. Agriculture, Ecosystems and Environment 139: 174-180. (VT)

Tucker, C.J., H.E. Dregne, and W.W. Newcomb. 1991. Expansion and contraction of the Sahara desert from 1980 to 1990. Science 253: 299-301. (VP)

Tucker, C.J., W.W. Newcomb, S.O. Los, and S.D. Prince. 1991. Mean and inter-year variations of growing season normalized difference vegetation index for the Sahel 19811989. International Journal of Remote Sensing 12: 1133-1135. (VP)

Tucker, C. J., Newcomb, W.W., and Dregne, H. E., 1994. AVHRR data sets for determination of desert spatial extent. International Journal of Remote Sensing 15, 35473566. (VP)

Tucker, C.J., and S.E. Nicholson. 1999. Variations in the size of the Sahara desert from 1980 to 1997. Ambio 28: 587-591. (VP) 
Vittek, M., A. Brink, F. Donnay, D. Simonetti, and B. Desclée. 2014. Land cover change monitoring using Landsat MSS/TM satellite image data over West Africa between 1975 and 1990. Remote Sensing 6: 658-676. (VT)

Wardell, D.A., A. Reenberg, and C. Tottrup. 2003. Historical footprints in contemporary land use systems: forest cover changes in savannah woodlands in the Sudano-Sahelian zone.

Global Environmental Change 13: 235-254. (VT)

Weiss, E. \& L. Milich (1997): Errors in a standard method for generating interannual NDVI coefficient of variation (CoV) images, International Journal of Remote Sensing, 18: 37433748. (VP)

Verbesselt, J., A. Zeileis, and M. Herold. 2012. Near real-time disturbance detection using satellite image time series. Remote Sensing of Environment 123: 98-108. (VP)

Wittig, R., K. König, M. Schmidt, J. Szarzynski. 2007. A study of climate change and anthropogenic impacts in West Africa. Environmental Science and Pollution Research 14: 182-189. (VT)

Wood, E.C., G.G. Tappan, and A. Hadj. 2004. Understanding the drivers of agricultural land use change in south-central Senegal. Journal of Arid Environments 59: 565-582. (VT)

Woomer, P.L., L.L. Tieszen, G.G. Tappan, A. Touré, and M. Sall. 2004. Land use change and terrestrial carbon stocks in Senegal. Journal of Arid Environments 59: 625-642. (VT) 